\title{
Neonicotinoids in global agriculture: evidence for a new pesticide treadmill?
}

\author{
Lieneke Bakker $^{1}, \underline{\text { Wopke van der Werf }}^{2}, \underline{\text { Pablo Tittonell }}^{3,4,5}, \underline{\text { Kris A. G. Wyckhuys }}^{6,7,8}$ and Felix J. J. A. Bianchi $^{1}$
}

\begin{abstract}
Overreliance on synthetic insecticides in global agriculture is the outcome of a "pesticide treadmill," in which insecticideinduced pest resistance development and the depletion of beneficial insect populations aggravate farmers' pesticide dependencies. Examples of the pesticide treadmill have been witnessed repeatedly over the past seven decades, prompting the question whether the rapid uptake and usage patterns of neonicotinoid insecticides and their associated environmental impact are in accordance with this recurrent phenomenon. We hypothesize a conceptual framework in which treadmills are enforced by enabling or disabling drivers within four domains: pest management decisions at the farm level, characteristics of farming landscapes, science and technology, and societal demands. These drivers then tend to create a self-enforcing pesticide "lock-in." We then analyze several post-1950s historical case studies with reference to this framework, e.g., those involving sprays of the highly hazardous DDT and methyl-parathion, in which the pesticide treadmill was initiated, sustained, and broken, and compare this with current patterns in neonicotinoid use. Historical case studies further illustrate how treadmills occur in three phases in which (i) a limited number of insecticides are routinely used, (ii) resistance development of pests results in the increased crop injury, prompting increased frequency of applications with a wider range of products, (iii) breaking out of the pesticide "lock-in" by policy change and adoption of alternative technologies that lowered chemical inputs and improved agro-ecosystem functioning. The analysis shows similarities as well as differences between neonicotinoid usage patterns and historic pesticide treadmills, and provides guidance on how to effectively avoid or dismantle pesticide treadmills in global agriculture.
\end{abstract}

Key Words: agrochemical pollution; biodiversity loss; farmer decision making; global change; insecticide dependency; lock-in; neonicotinoids; pest management; pesticide treadmill; technological change

\section{INTRODUCTION}

Over the past years, there has been increasing concern over the broad environmental risks of neonicotinoid insecticides (EASAC 2015, Giorio et al. 2017, Pisa et al. 2017, Goulson 2018). Since their introduction in the 1990 s, neonicotinoids have rapidly diffused because of their systemic mode of action (MoA), high efficiency at low doses, and their presumed low toxicity to vertebrates including humans (but see Cimino et al. 2017, Berheim et al. 2019). Today, neonicotinoids are the most widely used insecticides in the world, being employed in more than 120 countries and on 450 crops (Douglas and Tooker 2015, SimonDelso et al. 2015). Neonicotinoids are increasingly used in a prophylactic fashion, e.g., seed treatments, thus intended to prevent build-up of pest populations. However, their widespread and unguided usage combined with a myriad of nontarget effects has prompted environmental concerns (Hallmann et al. 2014, Zimmermann and Stout 2016, Krupke et al. 2017, Calvo-Agudo et al. 2019), and has sparked calls for an all-out suspension of prophylactic insecticide usage and more sustainable pest management strategies (Foley et al. 2011, Ge et al. 2016, Milner and Boyd 2017).

Although efforts to promote ecologically-based pest management, including integrated pest management (IPM), have been successful in certain cases, such as protected cultivation, U.S. cotton, Brazilian sugarcane, or Mexico's mango (Naranjo and Ellsworth 2009, van Lenteren et al. 2018), they have fallen short of expectations in a large number of broad-acre field crops and vegetable systems (Orr 2003, Zalucki et al. 2009, Parsa et al. 2014). The overall net result has been an increase in global pesticide use (Popp et al. 2013) and a rise in their total toxicity loading in, e.g., U.S. agriculture (DiBartolomeis et al. 2019).

The vicious cycle by which resistance development to insecticides and decline of natural enemies of pests due to insecticides increases farmers' usage of and dependence on chemical-based pest management has been referred to as the "pesticide treadmill" (DeBach 1951, Hansen 1988, Turnbull and Hector 2010), and is an example of what is broadly called a "lock-in" in social sciences. A system is "locked-in" to a certain state if self-enforcing mechanisms in that state perpetuate the dominant behaviors, making it hard to change to other, potentially more desirable, states (Liebowitz and Margolis 1995, Cowan and Hultén 1996, Kline 2001, Perkins 2003, Kallis and Norgaard 2010). In agriculture, lock-ins have historically been examined in a reductionist manner by focusing on parts of the system, e.g., ecological interactions, economics, or technology adoption (Cowan and Gunby 1996, Vanloqueren and Baret 2009, Magrini et al. 2016, Flor et al. 2019). Here, we argue that dynamic changes in these domains are inextricably linked, and that the lock-in in the technology and agro-ecological domains cannot be understood without consideration of other relevant domains.

The rapid uptake of neonicotinoid insecticides and the associated environmental impacts prompt the question whether today's neonicotinoid use patterns are in accordance with the pesticide treadmill phenomenon. To address this question, we first propose

\footnotetext{
${ }^{1}$ Farming Systems Ecology Group, Wageningen University and Research, Wageningen, The Netherlands, ${ }^{2}$ Centre for Crop Systems Analysis, Wageningen University and Research, Wageningen, The Netherlands, ${ }^{3}$ Agroecology, Environment and Systems Group, Instituto de Investigaciones Forestales y Agropecuarias de Bariloche (IFAB), INTA-CONICET, San Carlos de Bariloche, Río Negro, Argentina, ${ }^{4}$ Agroécologie et Intensification Durable (AïDA), Centre de coopération Internationale en Recherche Agronomique pour le Développement (CIRAD), Université de Montpellier, Montpellier, France, ${ }^{5}$ Groningen Institute of Evolutionary Life Sciences, Groningen University, Groningen, The Netherlands, ${ }^{6}$ Chrysalis Consulting, Hanoi, Vietnam, ${ }^{7}$ China Academy of Agricultural Sciences, Beijing, People's Republic of China, ${ }^{8}$ University of Queensland, Brisbane, Australia
} 
a theoretical framework of the pesticide treadmill, considering four conceptual, interlocking domains within a social-ecological system. Second, to test this framework, we examine historic case studies of pesticide treadmills to identify potential enabling and disabling drivers. Third, we describe to what extent dynamics in global neonicotinoid use are consistent with the observed characteristics of historic cases. Finally, we discuss pathways to escape from the pesticide treadmill and implications of our findings for current pest management.

\section{FRAMEWORK OF THE PESTICIDE TREADMILL}

The pesticide treadmill is characterized by overuse of pesticides with frequent applications, high dosages, and the use of a limited range of active ingredients or MoAs, ultimately decreasing pesticide effectiveness through, for example, resistance development (Hansen 1988, Thrupp 1990, Deguine et al. 2008, Turnbull and Hector 2010, Ekström and Ekbom 2011, Jørgensen et al. 2018). However, the pesticide treadmill is also typified by other ecological and social features with complex socialecological interdependencies. An adequate understanding of these interdependencies requires insight into the interconnections within the social-ecological system because lock-in situations in the ecological system are enforced by drivers from the social system (Yletyinen et al. 2019). Conversely, to devise lasting resolutions and pursue long-term change, e.g., from a chemicaldependent toward an ecologically-based pest management, a socalled "total systems approach" is needed (Lewis et al. 1997) in which the complexities of underlying farm-level decisions and barriers for change are duly taken into account (Schut et al. 2014, Wyckhuys et al. 2018, Yletyinen et al. 2019). We hypothesize that there are four main domains that encompass feedback cycles that are embedded in the complex social-ecological system of global agriculture (Fig. 1). These domains in the agri-food system are interrelated and can possibly enforce or disable the pesticide treadmill.

\section{Farming}

The first domain, farming, is centered around on-farm pest management decision making. Modern farming systems are often typified by large-scale, genetically uniform monocultures with high input dependence and superior yields. In such systems, pest outbreaks are regularly facilitated by chemical fertilizer use, narrow rotations, and nearby sources for pest colonization (Brust and King 1994, Settle et al. 1996, Meehan et al. 2011). Also, the ephemeral nature, low plant diversity, and intense disturbance regime of many cropping systems constrain the potential of resident natural enemies to exert top-down control and contribute sufficiently to pest suppression (Wiedenmann and Smith 1997, Letourneau et al. 2012, Lundgren and Fausti 2015). These patterns are aggravated through an overuse of synthetic pesticides, which are often harmful for natural enemies (Hansen 1988, Settle et al. 1996), trigger pest resistance development (Simon-Delso et al. 2015), and induce secondary pest outbreaks (Gross and Rosenheim 2011, Hill et al. 2017). In turn, weakened biological control services further enforce farmers' dependency on insecticides (DeBach 1951, Hansen 1988, Turnbull and Hector 2010).

\section{Agro-landscapes}

Farm-level decisions on crop choice and management style play out at the landscape scale (Schellhorn et al. 2008), with agro- landscape simplification and area-wide disturbance regimes compromising life support functions for natural enemies (Meehan et al. 2011, Karp et al. 2018). Agriculture-dominated landscapes tend to harbor simplified, species-poor natural enemy communities (Tscharntke et al. 2007), while more diverse settings tend to benefit from a broader variety of natural enemies and enhanced pest suppression (Bianchi et al. 2006, Schellhorn et al. 2014, Liu et al. 2016, but see Karp et al. 2018). Conversion of (semi)natural habitats into intensively managed farmland deteriorates resource provision levels for natural enemies, thus hampering their ability to colonize crops and impact pest populations (Meehan et al. 2011, Letourneau 2012, Bianchi et al. 2013, Meehan et al. 2013). Also, certain pest management strategies are most effective when neighboring farmers, who operate under similar biophysical and socioeconomic contexts, adopt the same strategy. This could foster exchange of machinery and knowledge, increase cost effectiveness, and reduce costs, also referred to as "agglomeration economies" (Liebowitz and Margolis 1995, Bowman and Zilberman 2013, Parsa et al. 2014, Bell et al. 2016). Yet, farmers are no passive recipients of technologies. The potential of innovation and active experimentation by individual farmers should not be downplayed, and compelling examples exist of farmers developing effective context-specific integrated pest management strategies (Van den Berg and Jiggins 2007, Wyckhuys et al. 2019).

Fig. 1. A conceptual framework of the "pesticide treadmill." Drivers of "pesticide lock-in" exist within the ecological or social subsystems of the global agri-food system and can be located in the following domains: (I) farming (yellow), (II) agro-landscapes (green), (III) science and technology (blue), and (IV) society (pink). Each domain contains internal positive feedbacks (black cycles), but also interacts externally with other mechanisms and drivers of the pesticide treadmill (red cycle), enforcing the lock-in situation of pesticide use. Each domain is embedded in either the social (grey) or ecological system (white), except for agro-landscapes, which is linked to both. Influential actors are depicted on the sides and interactions with the agri-food system are indicated by black arrows. Actors can be of influence in different domains, and can play an enforcing or disabling role with respect to the "pesticide lockin."

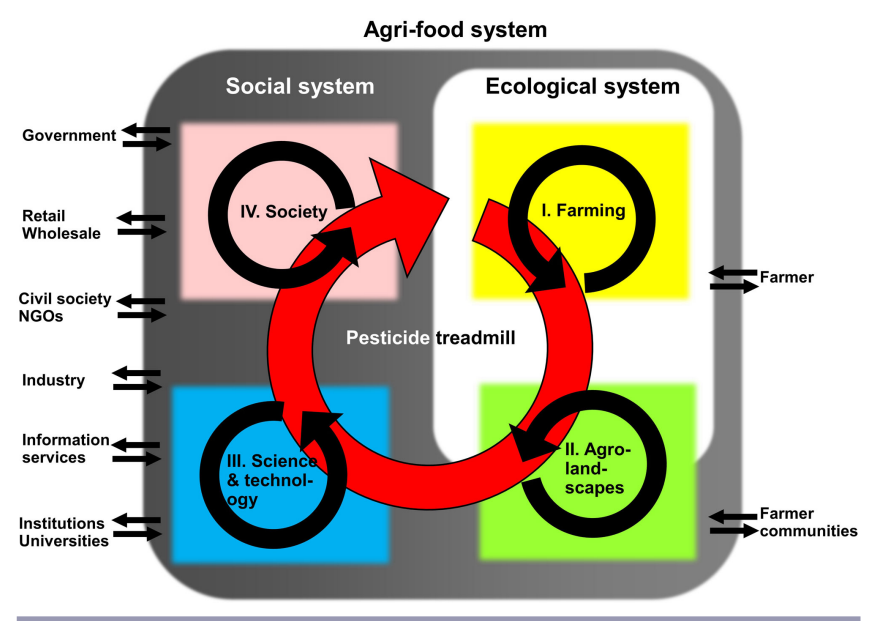




\section{Science and technology}

The ultimate fate of any (agricultural) innovation depends on coordination, pay-offs, and user perceptions, as well as on the investments made by end-users and myriad actors in both the private and public sector (Feder et al. 1985, Schut et al. 2014, Juma 2016). Subsequently, preference for a given pest management technology and ensuing pest problems trigger further investments in research and development to enable technological improvement and sustain user uptake (Liebowitz and Margolis 1995, Cowan and Gunby 1996, Pardey et al. 2010). This is often an incremental process that builds upon existing dominant technologies (Perkins 2003), and that is guided by vested interests, e.g., of owners of incumbent "legacy" technologies (Juma 2016). Central actors in the pesticide treadmill are the agrochemical industry, farmers, and the agro-advisory sector. Although the commercialization and privatization of knowledge can slow down innovation diffusion (Labarthe 2009, Lamine et al. 2010, Lamprinopoulou et al. 2014), this can also create "path dependencies," with farmers that have invested in particular types of equipment, knowledge, and skills becoming less likely to adopt agro-ecological innovations (Ruttan 1996, Wilson and Tisdell 2001, Vanloqueren and Baret 2009). These dependencies are often exacerbated for large-scale farmers who are prone to rely on risk-reducing technologies such as prophylactic seed treatment. The substitution of public advisory services by private-sector actors, e.g., commercial agroconsultancy firms, can reinforce some of these path dependencies (Lamine et al. 2010, Lamprinopoulou et al. 2014). Breaking the cycle is particularly difficult because the agro-industry has its own interest to maximize pesticide sales (Thrupp 1988, van den Bosch 1989), favoring technologies that capitalize on its in-house expertise and knowledge base, such as genetically modified crops, seed coatings, or agrochemistry (Popp et al. 2013). Diverging innovations in pest management are routinely perceived as threats by agrochemical industry actors, triggering active lobbying, distorted public sensitization, and an active deployment of roadblocks (van den Bosch 1989, Lamine et al. 2010, Juma 2016).

\section{Society}

Government, retail, wholesalers, consumers, and civil society organizations are important actors in the societal domain. Governments regulate the admission of pesticides and may influence farmers' decision making by imposing taxes or providing incentives, such as subsidies for greening measures or environmental schemes (Thrupp 1988, Boyd 2018). Regulatory bodies, such as the Environmental Protection Agency in the USA (U.S.-EPA) and the European Food Safety Authority in Europe, evaluate pesticide safety and advise governments on risks. Though these organizations solicit input from scientists, industry, and other stakeholders, their assessments are not flawless (Brühl and Zaller 2019). On the other hand, retail sets standards for quality and physical characteristics, e.g., cosmetic appearance of harvested produce (Pimentel et al. 1977), and pesticides are widely used by farmers to meet these standards (Norgaard 1976, Lamine et al. 2010, Lamine 2011, Morrissey et al. 2014). Food retailers can encourage farmers to change their production practices, for example, by issuing production mandates that include judicious use of pesticides by farmers (Macfadyen et al. 2015). Conversely, the presence of pesticide residues in agricultural produce and the associated, often unknown, risks for human health can generate demand and incentivization for pesticide-restrictive policies and pesticide-free production schemes (Boccaletti and Nardella 2000, Cimino et al. 2017).

\section{LESSONS FROM THE PAST: LOCK-IN AND ESCAPE FROM THE PESTICIDE TREADMILL}

We hypothesize that the pesticide treadmill involves a complexity of interacting enabling and disabling factors, which can be found in all four domains described above. To test this hypothesis, we selected historic case studies that met the following criteria: (i) availability of data on pesticide use in a cropping system of 30 years or more, (ii) availability of information on drivers of pesticide use, and (iii) documentation of lock-in and escape from the pesticide treadmill. We found five case studies that met these criteria: cotton production in Sudan, cotton production in Nicaragua, cotton production in Texas, USA, banana production in Costa Rica, and rice production in Indonesia.

To identify which drivers governed the lock-in and escape of the pesticide treadmill, we further divided the pesticide treadmill into three phases (Doutt and Smith 1971): subsistence and exploitation, crisis and disaster, and escape \& reorganization (Table 1). The subsistence and exploitation phase is characterized by an expanding crop production, but with still limited reliance on pesticides. Pest control measures are generally basic and limited in scope. The crisis and disaster phase is often triggered by the development of resistance against pesticides, and often results in soaring pest problems, increasing pesticide applications, and decreased profitability of crop production. The escape and reorganization phase is initiated by the notion that further increases in pesticide use will not solve the crises and alternative pest management approaches are explored (Doutt and Smith 1971, Eveleens 1983, Castle 1999). The Sudan and Nicaragua case studies are described below, while the case studies of the USA, Costa Rica, and Indonesia are given in Appendix 1.

\section{Case study Sudan}

Subsistence and exploitation

During the 1950s, the Sudan Plantation Syndicate centrally managed a major irrigation project in the state of Gezira and effectively developed cotton production (Eveleens 1983, Castle 1999). The cotton growing area increased from 90,000 ha in 1945 to 250,000 ha in 1975 , and only a limited number of cotton varieties were used. Cotton export was good for $71 \%$ of Sudan's national export in 1956 (Castle 1999). Crop management was the responsibility of tenants, but crop protection decisions were made by the central administration of the Gezira scheme. Cotton whitefly (Bemisia tabaci), a secondary pest, was controlled successfully with a combination of cultural and sanitary practices, and the cotton jassid (Jacobiasca lybica) was managed with broadspectrum pesticides. Although there was a rapid expansion of the total cotton area treated with the organochlorine DDT to $60 \%$ in 1950 s, the application frequency was still limited with one early season application per season until the 1960s (Fig. 2; Eveleens 1983, Castle 1999).

\section{Crisis and disaster}

Pest problems emerged with DDT applications becoming ineffective in resolving J. lybica outbreaks. Concurrently, B. tabaci reached the status of key pest because of negative effects on natural enemies by broad-spectrum pesticides (Eveleens 1983, 
Table 1. Overview of (enabling and disabling) drivers in the three phases of the pesticide treadmill. Drivers are numbered and allocated to the four domains (I-IV) of the theoretical framework. Common drivers are indicated in bold.

\begin{tabular}{|c|c|c|c|c|c|c|c|c|c|c|c|c|}
\hline \multirow[b]{2}{*}{$\underline{\text { Domains }}^{\dagger}$} & \multicolumn{4}{|c|}{ Subsistence and exploitation } & \multicolumn{4}{|c|}{ Crisis and disaster } & \multicolumn{4}{|c|}{ Escape and reorganization } \\
\hline & $\mathrm{I}$ & II & III & IV & $\mathrm{I}$ & II & III & IV & I & II & III & IV \\
\hline $\begin{array}{l}\text { Sudan: cotton } \\
\text { (Fig. 2) }\end{array}$ & 1,2 & 5,6 & $9, \mathbf{1 1}$ & $\mathbf{2 3 a}, 24$ & $3,4,8$ & 6 & $\begin{array}{c}12,13, \mathbf{1 4} \\
\mathbf{1 6}\end{array}$ & 28 & & & 9,22 & 31,32 \\
\hline $\begin{array}{l}\text { Nicaragua: } \\
\text { cotton } \\
\text { (Fig. 3) }\end{array}$ & 1,2 & 6 & $\mathbf{1 1}, 14,20$ & 23a, $24,26 a$, & $3,4,8$ & 5,6 & $\begin{array}{l}\mathbf{1 4}, 15, \mathbf{1 6} \\
18,19,21\end{array}$ & $\begin{array}{c}23 \mathrm{a}, 26 \mathrm{a}, 28, \\
29\end{array}$ & & 7 & $\mathbf{9}, 19, \mathbf{2 2}$ & $\begin{array}{c}23 \mathrm{a}, 25, \mathbf{3 1}, \\
\quad 33,34\end{array}$ \\
\hline 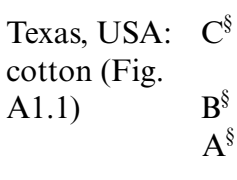 & 1,2 & 6 & 9, 10a, 11 & $\begin{array}{l}\text { 23a, } 27 \\
\quad 33\end{array}$ & $3,4,8$ & 6 & $\begin{array}{c}13,15,16 \\
18\end{array}$ & 21 & & 7 & $\begin{array}{c}\mathbf{9}, 21 \\
\mathbf{9}, 17,21\end{array}$ & $\begin{array}{c}31 \\
31,34\end{array}$ \\
\hline $\begin{array}{l}\text { Costa Rica: } \\
\text { banana } \\
\text { (Fig A1.2) }\end{array}$ & 1,2 & 6 & $\mathbf{1 1}, 14,18$ & 23a & $3,4,8$ & 6 & $\mathbf{1 4}, 18,19$ & $21,22,28$ & & & $\begin{array}{c}9,10 b \\
17\end{array}$ & $31,23 b$ \\
\hline $\begin{array}{l}\text { Indonesia: rice } \\
\text { (Fig A1.3) }\end{array}$ & 1,2 & 5,6 & $\mathbf{1 1}, 12,13$ & 23a, 25, 26a & $3,4,8$ & 5,6 & 14,20 & $\begin{array}{c}23 \mathrm{a}, 24,26 \\
28,29,30\end{array}$ & & & 9,22 & $31,26 b$ \\
\hline $\begin{array}{l}\text { Neonicotinoids } \\
\text { (Fig. 4) }\end{array}$ & 1,2 & & & & $3,4,8$ & 5,6 & 14 & 31 & & & & 31 \\
\hline \multicolumn{13}{|c|}{ 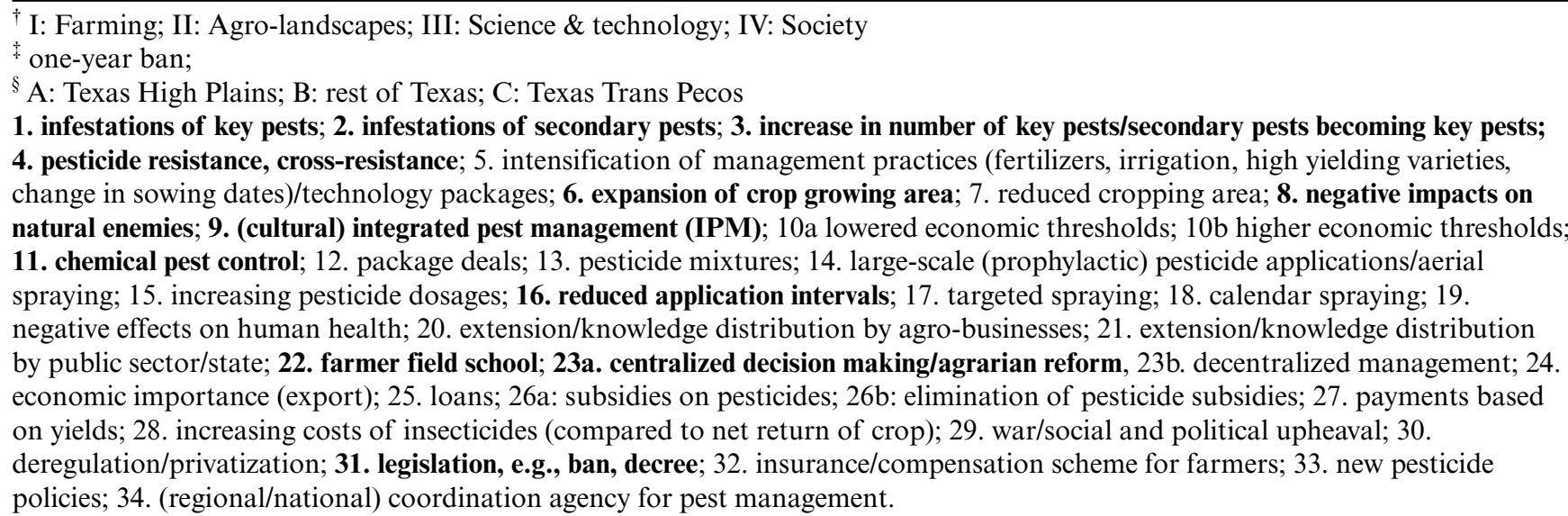 } \\
\hline
\end{tabular}

Castle 1999). This increasing pest pressure resulted in more frequent and higher dose applications of organochlorine insecticides. In the 1970s, pest problems aggravated by insecticide resistance, pest resurgence, and the appearance of several secondary pests, such as B. tabaci and cotton bollworm (Helicoverpa armigera), triggered more applications with a wider spectrum of insecticides, including DDT, endrin, and dimethoate (Eveleens 1983, Stam et al. 1994, Castle 1999, Bashir et al. 2003). Contractual "package deal" agreements were made between cotton growers and agrochemical companies to ensure the control of $H$. armigera, whereby the agrochemical companies were responsible for all pest control operations and guaranteed a minimum yield to farmers. Although cotton acreage under these package deals quickly increased from 30,000 ha in 1973 to 80,000 ha in 1978, cotton pests continued to reach outbreak levels and broad-spectrum pesticides, such as monocrotophos, were applied using aerial spraying. Although this approach was initially effective against $H$. armigera, whitefly populations were unaffected and caused severe crop damage. Over time, pesticide application frequency increased from an average of one spray per season in 1960-1961 to eight sprays per season in 1980-1981 (Eveleens 1983).

\section{Escape and reorganization}

By the mid-1970s cotton production was no longer economically viable because of emerging outbreaks of pesticide-resistant whitefly populations. This led to a ministerial decree issuing a ban on package deals and (mixtures containing) DDT (Eveleens 1983, Castle 1999). The immediate result was a shift in insecticide classes toward endosulfan, newly registered pyrethroids, and aldicarb (Eveleens 1983). Concurrently, IPM programs were developed 
based on biological control of $H$. armigera and higher economic damage threshold levels, permitting a reduction in pesticide application frequency from eight to three per season without yield reduction (Bashir et al. 2003). Although farmer training and education were central to reach this achievement, another key success factor was the launch of innovative insurance schemes for early IPM adopters, thus compensating farmers for pest-induced yield loss. This insurance reduced farmers' uncertainty and associated risk-aversive behavior, and enabled uptake of IPM packages that involved improved water management, insectresistant varieties, and biological control (Stam et al. 1994, Bashir et al. 2003).

Fig. 2. Time line representing enabling (upward arrows) and disabling (downward arrows) drivers of pesticide use in cotton production in Sudan from 1945 to 1995 . The graph indicates the number of insecticide applications per year (Eveleens 1983, Bashir et al. 2003). Dashed lines indicate approximate times of the transition to a new phase of the treadmill. Colors referring to domains (I-IV) in the framework: (I) farming (yellow), (II) agro-landscapes (green), (III) science and technology (blue), and (IV) society (pink). Numbers and arrows indicate drivers of the treadmill; (1) pest outbreaks (yellow), cropping intensification (green), early season sprays (blue), centralized crop protection decision making (pink); (2) cotton export $71 \%$ of national export; (3) pesticide resistance and secondary pest resurgence (yellow), expansion of cotton growth area (green), pesticide mixtures and pesticides with different modes of action (blue); (4) secondary pest outbreaks (yellow), package deals (blue); (5) maximum cotton acreage (green), increasing crop protection costs (pink); (6) pesticide resistance to organophosphates; (7) start integrated pest management program; (8) ban on DDT and package deals; (9) development of biological control strategies, and large-scale demonstrations that fewer pesticides could be used; (10) economic threshold levels for four major cotton pest species were revised, improvement of the role of biological control agents in cotton crop protection, implementation of food crops in the cotton rotation.

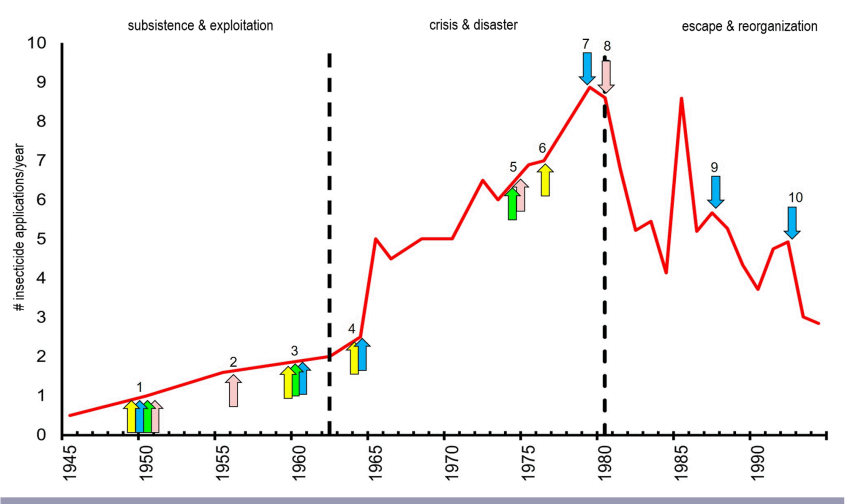

In summary, in the case of Sudan we identified drivers from all four domains in the conceptual framework (Table 1; Fig. 1). Drivers from the "farming" and "agro-landscapes" domains were most prominent in the "subsistence and exploitation" phase, while drivers of the "science and technology" and "society" domains were dominant in the "escape and reorganization" phase (Table
1). Although pest problems emerged with the expansion of cotton production and intensive management practices, Castle (1999) argues that the centralized decision making of the Gezira scheme contributed to a range of socioeconomic problems influencing the agricultural system, such that tenant farmers cared less about cotton production. Ultimately, the crises were resolved by deploying IPM measures (Eveleens 1983, Stam et al. 1994, Castle 1999, Bashir et al. 2003). Several economic, social, and political drivers contributed to the IPM success, with a central element being a compensation scheme for yield reduction for early IPM adopters, reducing farmers' uncertainty and influencing risk perception (Table 1; Bashir et al. 2003).

\section{Case study Nicaragua}

\section{Subsistence and exploitation}

Before the 1950s, 3000 ha of cotton was grown in western Nicaragua and the boll weevil (Anthonomus grandis) was the main pest. Boll weevil outbreaks were combatted with large-scale applications of DDT and methyl parathion (Fig. 3). During the 1960 s, cotton acreage expanded to 150,000 ha and cotton became an engine of growth of the Nicaraguan national economy. Not only did the national government provide direct subsidies to facilitate farmers' purchasing of pesticides (Vandermeer 1991, Murray 1994), chemical producers enjoyed free rein because there was a lack of public-sector infrastructure and knowledge distribution of cultural and nonchemical pest control practices (Murray 1994). Even though human poisonings and deaths urged the government to ban methyl parathion in 1953, cotton grower associations and related lobby groups forced the ban to be lifted in the same year (Swezey et al. 1986).

\section{Crisis and disaster}

By the mid-1960s the area of cotton production exceeded 150,000 ha ( $40 \%$ of the cultivated area in the whole of Nicaragua) and further increased to 175,000 ha in 1973. Yet, from 1965 onward, cotton yields dropped and pesticide-inflicted ecological disruption became evident with an emergence of several secondary pests, including the American cotton bollworm (Helicoverpa zea), armyworm (Spodoptera sunia) and B. tabaci (Swezey et al. 1986). To safeguard yields from pest attacks, pesticide usage rates increased from five per year in the mid-1950s to 28 by the late $1960 \mathrm{~s}$, primarily through calendar-based application schemes devised by the agrochemical industry. In addition, farmers that cultivated cotton depended heavily on bank loans, which were directly tied to crop yields. Loan contracts prescribed the type of chemicals to be used and the number of applications to obtain target yields (Murray 1994). Yet, average yields fell by $15-30 \%$, and insecticide resistance and the emergence of secondary pests became more prevalent (Swezey et al. 1986).

\section{Escape}

In 1966 a national cotton commission was established to mitigate the increasing cotton pest problems and a cotton research station was opened in 1967. These initiatives coincided with an initiative of the Food and Agriculture Organization (FAO) to develop an IPM program and reorient pest control practices in Nicaragua. This IPM program included training of researchers and technicians, establishment of demonstration fields, and the monitoring of insect populations. Nonchemical and lowchemical agronomic practices were promoted to prevent 
ecological disruption, which included scouting, increased economic damage thresholds, coordinated releases of parasitic wasps, and the promotion of microbial pesticides and other biological control agents (Murray 1994). The IPM program was implemented in the 1970 s, and achieved a $30 \%$ reduction in pesticide use, higher cotton yields and a substantial increase in farmer profits (Swezey et al. 1986).

Fig. 3. Time line representing enabling (upward arrows) and disabling (downward arrows) drivers of pesticide use in cotton production in Nicaragua from 1945 to 1995 . The graph indicates the number of insecticide applications per year (Swezey et al. 1986, Murray 1994). Dashed lines indicate approximate times of the transition to a new phase of the treadmill. Colors referring to domains (I-IV) in the framework: (I) farming (yellow), (II) agro-landscapes (green), (III) science and technology (blue), and (IV) society (pink). Numbers and arrows indicate drivers of the treadmill; (1) key pest outbreaks (yellow), economic importance of cotton (pink), (2) increased acreage of cotton production (10,500 ha); (3) one-year ban on methyl parathion; (4) agrarian reform; (5) insecticide resistance (yellow) and decrease natural enemy populations (green); (6) key pests from 5 to 9 (yellow), cotton on $40 \%$ of all agricultural land (green), calendar scheduled pesticide applications (blue); (7) drift of pesticide applications; (8) integrated pest management (IPM) program; (9) increase in cotton acreage (175,000 ha), 5-year drought (green), pest outbreaks (yellow); (10) few IPM specialists (blue), loans for pesticide imports, nationalized cotton farms, war (pink); (11) pest outbreak; (12) ban and innovative pesticide policies (pink), regional IPM programs (blue); (13) state decree on mandatory IPM measures; (14) economic crisis, Contra War.

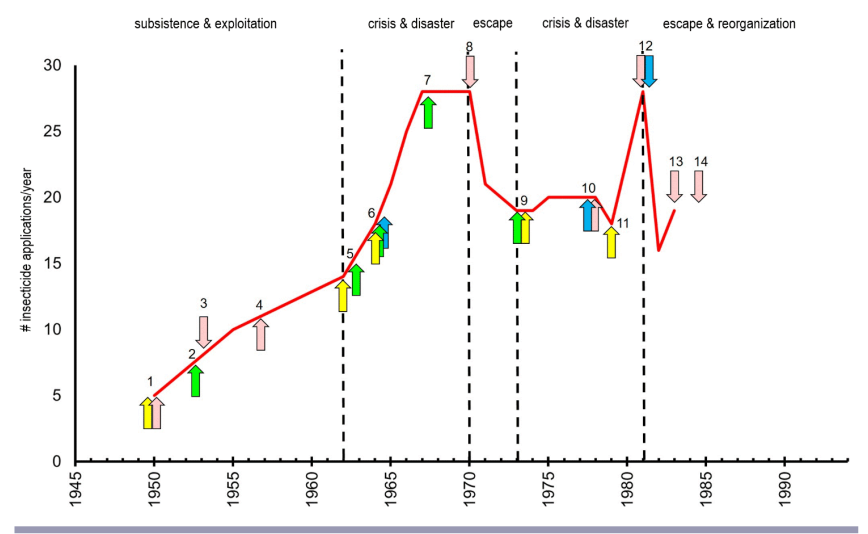

\section{Crisis and disaster}

Yet, the promotion of IPM was hindered by insufficient capacity of trained technicians and poorly developed national agricultural research and extension programs (Murray 1994). Droughtinduced outbreaks of cotton leaf miners (Bucculatrix thurburiella), whiteflies (B. tabaci), and bollworms contributed to a relapse in the use of pyrethroids (Swezey et al. 1986, Murray 1994). Declining yields and escalating pest problems favored the quick fix that pesticides promised, prompting a relapse to pesticide use. In addition, banks offered incentives, e.g., bonuses, to farmers who harvested cotton at yield levels that exceeded normal yield levels, which spurred farmers' short-term vision instead of a long-term approach, such as IPM. Although pesticide application frequencies did not increase in the late 1970s, farmers did increase dosages (Murray 1994).

\section{Escape and reorganization}

The Sandinista-led revolution changed the political landscape of Nicaragua. A second transition to IPM was attempted in 1982, this time driven by a ban on organochlorine-based insecticides, the initiation of a National Pesticide Commission to regulate pesticide imports, and a renewed effort to implement IPM programs. The latter was attempted through coordinated training of IPM specialists and extension officers, and with a special focus on the suppression of the primary pest, the boll weevil (Swezey et al. 1986). For example, the establishment of trap crops for boll weevil as a prophylactic treatment reduced the number of pesticide applications needed to suppress boll weevil. The importance of this measure was emphasized with a state decree that made it mandatory to take measures to suppress boll weevil between cropping seasons (Vandermeer and Andow 1986). In addition, there was a focus on experiments with bacterial pesticides to replace existing chemical products. This was a popular measure for farmers because it did not imply major changes in the cotton production process. This IPM approach reduced the number of insecticide applications in cotton, and by 1984 became one of the largest IPM programs in Central America (Swezey et al. 1986). However, the success of this program was undermined by the social and economic difficulties in Nicaragua in the late 1980s (Murray 1994), and cotton acreage decreased to 35,000 ha in 1990. Although a decline in pesticide use was observed (Fig. 3), this may be ascribed to a decline in cotton acreage, the economic crisis in Nicaragua resulting in soaring pesticide prices, and declining international market prices for cotton (Swezey et al. 1986, Thrupp 1988, Vandermeer 1991, Murray 1994). Moreover, the Contra War hindered IPM workers and pesticide inspectors (Thrupp 1988).

In summary, most of the identified drivers in Nicaragua fit in one of the four domains of the conceptual framework (Table 1; Fig. 3). Enabling drivers from the "farming" and "agro-landscapes" domains were mainly found in the "subsistence and exploitation" phase but were virtually absent in the "escape and reorganization" phase (Table 1). Ultimately, the escape from the insecticide use lock-in was fostered by drivers of the "science and technology" and "social" domains, resulting in the implementation of the IPM approach.

\section{THE CASE OF NEONICOTINOID INSECTICIDES}

\section{Subsistence and exploitation}

Imidacloprid was the first neonicotinoid introduced on the market in the early 1990s, quickly followed by acetamiprid (1995), nitenpyram (1995), thiamethoxam (1998), thiacloprid (2000), clothianidin (2001), and dinotefuran in 2002 (Jeschke et al. 2011). A pre-emptive approach (using pretreated or neonicotinoidcoated seeds) is routinely applied to large areas of grain and oilseed crops in developed countries, irrespective of pest presence, infestation pressure, or cropping history (Douglas and Tooker 2015, EASAC 2015, Simon-Delso et al. 2015). For example, 42 million hectares of cropland in the U.S. were planted with neonicotinoid-coated seeds, equalling $57 \%$ of total area planted with maize, soybean, and cotton in 2011 (Douglas and Tooker 
2015). Currently, neonicotinoids are used in over 120 countries as seed treatment in more than 140 crops, including cotton, corn, cereals, sugar beet, oilseed rape, and others (Jeschke et al. 2011). With a $24 \%$ market share, neonicotinoids are currently the most used class of insecticides (Jeschke et al. 2011, Alburaki et al. 2015, Simon-Delso et al. 2015, Sparks and Lorsbach 2017). Because the patents on all neonicotinoids have expired, the supply of generic products is likely to increase and open up the market, possibly leading to a price reduction of neonicotinoids (Jeschke et al. 2011). Given this expansion of neonicotinoids into major markets worldwide, the number of resistance cases is expected to rise (Whalon et al. 2008).

\section{Crisis and disaster}

The widespread use and environmental persistence of neonicotinoids has raised concerns about exposure and associated impacts on nontarget organisms (Chagnon et al. 2015, Douglas and Tooker 2016, Woodcock et al. 2016, Calvo-Agudo et al. 2019). Exposure to neonicotinoids can occur via different pathways, including pollen, nectar, guttation fluids, soil, air, and noncrop vegetation (Roubos et al. 2014, Chagnon et al. 2015, Mogren and Lundgren 2016, Calvo-Agudo et al. 2019), and sublethal and lethal effects have been reported for pollinators (Blacquière et al. 2012, Whitehorn et al. 2012, Rundlöf et al. 2015) and natural enemies, potentially undermining vital pollination and biological control services (Pisa et al. 2015, 2017, Calvo-Agudo et al. 2019). High levels of exposure were reported for different species of farmland birds (Humann-Guilleminot et al. 2019), and sublethal impacts have been reported for large vertebrates, such as deer (Gibbons et al. 2015, Berheim et al. 2019). Residues of neonicotinoids have been found in honey all over the world, at potentially harmful concentrations for nectar-feeding insects in $48 \%$ of the samples (Mitchell et al. 2017).

Since the introduction of neonicotinoids more than a 1000 cases of resistance have been reported (Mota-Sanchez and Wise 2020). More than half of these resistance cases have been reported for economically important pests of different crops across the world, especially in America, Europe, and Asia (Nauen and Denholm 2005, Jeschke et al. 2011). For instance, 250 and 105 resistance cases are reported for $B$. tabaci and A. gossypii, respectively, which are important polyphagous pests in cotton and vegetables (MotaSanchez and Wise 2020). The green peach aphid, Myzus persicae (Sulzer), is the most economically important aphid pest worldwide and 120 cases of neonicotinoid resistance have been reported in flower, crops, fruit, trees, grains, tobacco, or vegetables (Bass et al. 2015, Mota-Sanchez and Wise 2020). The brown planthopper $N$. lugens is the most economically significant pest of rice (Mota-Sanchez and Wise 2020) and populations of $N$. lugens (Stål) show widespread resistance across Asia (Bass et al. 2015). Insecticide resistance has led in some cases to increased application rates of neonicotinoids, or replacement of neonicotinoids by older and more harmful insecticides (Jeschke et al. 2011, Chagnon et al. 2015, Simon-Delso et al. 2015, Douglas and Tooker 2016).

The prophylactic use of neonicotinoids has deepened farmer dependency on insecticides, and created a system in which farmers experience "deskilling" and lack sufficient resources or experience to transition toward more ecologically-based pest management approaches (e.g., LaCanne and Lundgren 2018, Wyckhuys et al.
2019). Core components of the IPM approach, such as pest monitoring and threshold-based decision making, have become redundant with prophylactic use of neonicotinoids (EASAC 2015). Moreover, the current use of neonicotinoids is facilitated by relatively low costs, convenient application modes, existence of tailored supply chains, and the necessary technology and machinery for on-farm application. Even if farmers prefer to use nontreated seed, accessing it can be challenging (Simon-Delso et al. 2015, Busch et al. 2020).

\section{Escape and reorganization?}

Currently, there are several cases of legislation to regulate neonicotinoid use. In 2018, the European Union (EU) prohibited the use of seeds treated with the neonicotinoids clothianidin, thiamethoxam, and imidacloprid for open-field cultivation (Regulation (EU) 2018/784; EU 2018). The U.S.-EPA has announced a registration review update on imidacloprid, clothianidin, thiamethoxam, and dinotefuran for 2020 (U.S.-EPA 2020), and the state of Maryland in the USA has issued a ban on the sales of neonicotinoids effective in 2018 (State of Maryland 2016). Though some restrictions are aimed at flowering field crops to prevent their impacts on pollinators and other flower visitors, nonflowering crops can pose equally high risks to these organisms (Calvo-Agudo et al. 2019). In response to an earlier EU moratorium on neonicotinoids, multiple EU member states have applied for emergency authorizations to continue the use of neonicotinoids (EFSA 2018). Some farmers and associated lobby groups are trying to obtain derogations because neonicotinoids are considered indispensable in modern agriculture. Clearly, the outcome of this debate will have important implications for farmers, agrochemical industry, and society as a whole.

\section{DISCUSSION}

By contrasting the rapid global use of neonicotinoid insecticides with five historic cases of the pesticide treadmill (Table 1, Figs. 2, 3, and 4, Appendix 1), we generated three key insights: (i) the uptake and reduction of insecticides are influenced by drivers from different social-ecological domains, including "farming," "agro-landscapes," "science and technology," and "society," (ii) a pesticide treadmill is enforced by drivers from all four domains, while drivers from "science and technology" and "society" are most important for the escape from the pesticide treadmill, and (iii) the neonicotinoid case shows many similarities with historic case studies, but also deviates in some respects. Important differences are that the uptake of neonicotinoids occurred at a fast pace and a global scale for several crops, while documented historic examples of the pesticide treadmill are rather restricted to particular geographies and cash crops. Furthermore, while the pesticide treadmill in the historic case studies was only counteracted after major crop losses, current legislation to regulate the use of neonicotinoids is strongly motivated by concerns about impacts on nontarget organisms and the environment, and less by mitigating resistance development and the associated crop losses.

Historical case studies revealed that the identified drivers can be categorized in the four domains of the conceptual framework (Table 1), with similar patterns in Sudan, Nicaragua, USA, Costa Rica, and Indonesia (Table 1, Appendix 1). The case studies show that there are two important elements initiating the pesticide treadmill that can be found in the "farming" and "agro- 
landscapes" domains; (i) frequent pesticide use triggers resistance development and pest outbreaks, and (ii) impacts of pesticides on natural enemies release pests from top-down control (Settle et al. 1996), thus locking farmers into pesticide-based management (Swezey et al. 1986). However, farm-level decisions may also be influenced by drivers in the social and technological domains (Fig. 1), many of which are beyond control of individual farmers and the "farming" domain. Hence, it is important to consider on which level transitions could be initiated (Kinzig et al. 2006).

Although the pesticide treadmill may be enforced by drivers from all four domains, agroecological problems lie often at the base of the pesticide treadmill (Table 1). The large-scale monocropping of a limited number of crops offers an abundant and high-quality food resource for herbivores and often initiates the build-up of pest populations. Resistance of key pests to pesticides, pest resurgence, and secondary pest species usually result in increases in the quantity, frequency, and diversity in MoA of the pesticides used to manage pests. In addition, centralized management and decision making, e.g., through bank loans tied to crop yields, subsidies on pesticides, and package deals with agro-industry, accelerated the pesticide treadmill in historic case studies. Yet, "science and technology" and "society" regularly helped unlock and accelerate the "escape and reorganization" phase. That is, scientific progress and farmer-led innovation, e.g., in agro-ecology and biological control, became the central element of farmer field schools (FFS) in, e.g., Sudan, Nicaragua, and Indonesia (Swezey et al. 1986, Settle et al. 1996, Bashir et al. 2003). On-farm validation of IPM and biological control directly contributed to the escape of the treadmill by millions of farmers (Matteson 2000, Sigsgaard 2000). For example, the FFS movement in Indonesia consisted of three pillars in which (i) pesticide use was widely recognized as a key driver of pest outbreaks, (ii) millions of farmers were trained on nonchemical pest management, and (iii) pesticide use was cut substantially and biological control experienced a bonanza (Settle et al. 1996, Matteson 2000, Thorburn 2015).

Our analysis suggests that current neonicotinoid use is in the "crisis and disaster" phase of the pesticide treadmill (Fig. 4). The widespread use, persistent nature, and toxicity of neonicotinoids to a broad range of beneficial organisms are strong indications that many ecological and societal problems that accompanied the developments of pesticide use as described in our case studies still persist (Figs. 2 and 3 vs. 4; Chagnon et al. 2015). Cases of resistance against neonicotinoids are continuously increasing both in terms of number of pest species and countries (MotaSanchez and Wise 2020). For instance, neonicotinoids are identified as the driver of renewed pest problems and increased pesticide use in Asian rice systems (Bottrell and Schoenly 2012), suggesting that the lessons learned from IPM training have been abandoned. Although resistance has commonly been solved by replacing one active ingredient with another, e.g., organochlorines were replaced by carbamates and pyrethroids (Sparks and Lorsbach 2017), the case studies indicate that this is not a sustainable strategy for future agricultural production. From a socio-technological perspective, especially prophylactic use of neonicotinoids as a standard practice has created a system in which many farmers lack resources, skills, and experience to implement a different pest management strategy (EASAC 2015). Although a diverse range of alternatives can replace neonicotinoids, e.g., scouting, decision-support tools, low-impact pesticides, or biological control, accurate and unbiased information on the efficacy and cost-effectiveness of (prophylactic) neonicotinoid usage is needed. Because extension services are commonly provided by chemical companies (Giannakas and Fulton 2005, Savary et al. 2012), information on neonicotinoid use is often one-sided as it reaches the farmer through programs sponsored by pesticide manufacturers (Tooker et al. 2017). Farmers are regularly led to believe that a phase-out of neonicotinoids will entail yield reductions and loss of profit, and they are therefore reluctant to reduce their use of insecticides (Goulson 2013, Furlan et al. 2018), with such claims possibly being part of a deliberate misinformation strategy (Oreskes and Conway 2011, Juma 2016, Furlan et al. 2018). Yet, yield gains of neonicotinoid seed coatings were negligible in U.S. soybean (Myers and Hill 2014, Mourtzinis et al. 2019), questionable in U. S. maize (Seagraves and Lundgren 2012, Krupke et al. 2017), and farm-level profits can increase substantially for growers that abandon these technologies (LaCanne and Lundgren 2018).

\section{Escape and reorganization of neonicotinoid use}

Cowan and Hultén (1996) formulated six conditions for a lasting escape from technology lock-in. These are a crisis in the existing technology, changing regulations, technological or cost breakthrough, changes in "taste" by society, active niche markets and early adopters of emerging technologies, and scientific results questioning the technology in use. Given the above, we consider that a slow but steady escape from the neonicotinoid use lock-in is underway. First, the continuous resistance development, stricter residue requirements, and changing regulatory landscape are posing major challenges to the agrochemical industry and farmers (Sparks and Lorsbach 2017, Jørgensen et al. 2018, Pretty 2018). Although we recognize the multiple challenges associated with a ban of a popular insecticide, a properly aligned design and implementation of effective, economically viable, and practicable alternatives and broader agricultural systems redesign can enable a large-scale, lasting transformation of pest management systems (Pretty 2018, Sponsler et al. 2019). In society, change in "taste" is reflected in the swelling support of consumers, NGOs, governments, and farmers for "green" and environmentally friendly agriculture (Byerlee et al. 2009, van Lenteren et al. 2018). In the meantime, scientific reports emphasize the environmental and nontarget impacts of neonicotinoids and question their efficacy (Seagraves and Lundgren 2012, EASAC 2015, Cimino et al. 2017, Mourtzinis et al. 2019). Finally, the development of agroecological niches, innovations across agri-food value chains, and the uptake of no or low-pesticide practices by early adopters allow adaptive learning and permit broader diffusion of nonchemical alternatives (Cowan and Hultén 1996, Vanloqueren and Baret 2009). The case studies illuminate various elements that are central to effectively mitigate pesticide use in agri-food systems, and thus create room for more equitable and sustainable forms of agricultural production. For example, the Sudan IPM initiative proved successful because of compensation schemes for yield reduction tailored to early IPM adopters, thus reducing farmers' uncertainty and influencing risk perception (Bashir et al. 2003). In Nicaragua, key components were the coordinated training of IPM specialists and extension officers, and the promotion of microbial pesticides that could be easily incorporated in farming operations (Swezey et al. 1986). The case 
Fig. 4. Time line of neonicotinoid use and developments from 1990 to the present. The graphs indicate the amount of neonicotinoid use per year, including seed treatments for three countries; USA (orange; million kg applied/year from 1992 to 2014 ), UK (green; kg applied/ year from 1994 to 2016), and the Netherlands (yellow; kg applied/year from 1995 to 2016). Data are obtained from U.S.

Geological Survey (EPest-Low estimate) for the USA (USGS 2019), from Pesticide Usage Surveys for the UK (Fera 2020), and from CBS StatLine for the Netherlands (Statline 2019). Dashed lines indicate the possible timing of the transition to a new phase of the treadmill. Colors referring to domains (I-IV) in the framework: (I) farming (yellow), (II) agro-landscapes (green), (III) science and technology (blue), and (IV) society (pink). Numbers and arrows indicate drivers of the treadmill; (1) introduction of imidacloprid; (2) introduction of acetamiprid and nitenpryam; (3) neonicotinoid resistance in B. tabaci; (4) introduction of thiamethoxam; (5) introduction of thiacloprid (blue), neonicotinoid resistance in Leptinotarsa decemlineata (Colorado potato beetle; yellow); (6) introduction of clothianidin; (7) introduction of dinotefuran (blue), honeybee mortality linked to neonicotinoids (green), neonicotinoid resistance in A. gossypii (yellow); (8) patent expiry on imidacloprid; (9) neonicotinoid resistance in N. lugens and M. persicae (yellow), $80 \%$ seed treatments with neonicotinoids (green); (10) patent expiry other neonicotinoids; (11) two year moratorium on three neonicotinoids in EU; (12) ban on three neonicotinoids in EU. For USA specifically: (A) imidacloprid resistance in L. decemlineata; (B) imidacloprid and thiamethoxam resistance in M. persicae and B. tabaci; (C) more than 50\% of area planted with maize, soybean, and cotton treated with neonicotinoids; (D) thiamethoxam resistance in A. gossypii; (E) registration review update in the USA.

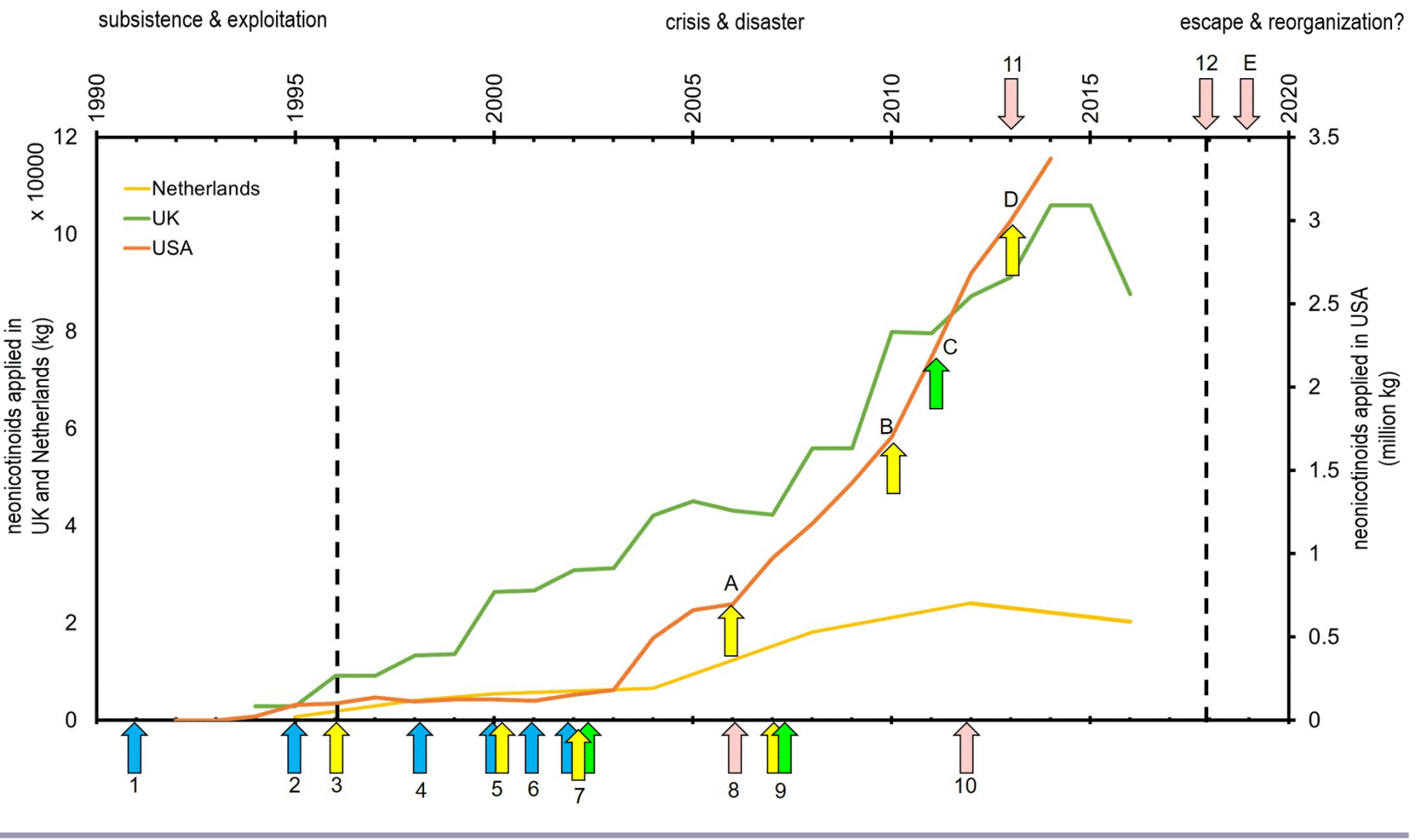

of Texas cotton shows how a coordinated effort by farmers was needed to switch practices (Cowan and Gunby 1996). In Costa Rica, an increased awareness of pest issues, the development of economic damage threshold levels, and an ultimate ban on all insecticide treatments brought about change (Thrupp 1990). Although a country-wide ban on 57 pesticides constituted a first step toward change in Indonesia, the official (government) endorsement of IPM and hands-on training of millions of farmers on nonchemical pest management ultimately permitted an up to $60 \%$ decrease of insecticide use (Oka 1991, Settle et al. 1996, Thorburn 2015). The IPM FFS movement fostered the escape of the treadmill for millions of farmers through farmer innovations, tailored extension programs, and on-farm validation of IPM and biological control. Endorsement of these developments by national governments and international organizations, like FAO, permitted a fast transition toward ecologically-based management techniques (Swezey et al. 1986, Bashir et al. 2003).

At present, a suite of alternative pest control methods are available, including economic damage threshold levels, microbial control agents, semiochemical methods, and biological control (Barzman et al. 2015, Furlan and Kreutzweiser 2015, Furlan et al. 2018, Jactel et al. 2019), even though not all alternatives rank well in terms of efficacy, applicability, durability, and practicability (Jactel et al. 2019). The recent emergence of "disruptive innovations" (Juma 2016), such as robotic weeders, farm-level sensing, weed-suppressing intercrops, or drone-based 
delivery of natural enemies carries ample promise (Lamichhane et al. 2016, Iost Filho et al. 2020). Political initiatives are needed to overcome eventual economic constraints, ease farmer transitions, and influence the trade-off between costs and benefits of insecticide use (Clark and Tilman 2017, Milner and Boyd 2017, van Lenteren et al. 2018). Once alternative technologies are permitted to mature and reach scalability, without involvement of the agrochemical industry, they can break the multidecade model of chemically dependent agriculture. Yet, transitions also need to occur in social domains, with effective (two-way) scientistfarmer communication, coordination, and cooperation being determinants of success. Tailored education of farmers, e.g., to fill existing agro-ecological knowledge gaps (Wyckhuys et al. 2019), possibly can spark on-farm experimentation and adoption of nonchemical management alternatives (Pretty 2018).

To conclude, transitions in pest management cannot be seen in isolation from other components of the social-ecological system (Lewis et al. 1997, Lamine et al. 2010, Lamine 2011, Letourneau 2012, Barzman et al. 2015). The case studies show that regulations (e.g., bans or state decrees), IPM programs, and introduction of biological control tactics help to develop systems that are less pesticide dependent (Table 1). Thereby, fostering the adoption of sustainable management practices requires training, education, and acceptance of new approaches by farmers, parallelled by facilitation through policy makers and regulators (EASAC 2015, Furlan and Kreutzweiser 2015, Dudley et al. 2017, Milner and Boyd 2017, Sponsler et al. 2019). To facilitate "escape and reorganization" of current neonicotinoid-based pest management, top-down regulations need to be paired with bottom-up farmerfirst approaches of pest management (Matteson 2000, MacMillan and Benton 2014, Wyckhuys et al. 2019), and the active pursuit of management practices that do not involve synthetic pesticides, such as agro-ecology. Neonicotinoid use has triggered a new, globe-spanning cycle of the pesticide treadmill, yet promising and resolute steps are being taken to escape this lock-in. When paired with adequate technological innovation, supporting policies, sound public education, and institutional change, the current product bans can enable a large-scale, lasting adoption of ecologically underpinned farming schemes that will concurrently benefit farmers, consumers, and the environment.

\section{Responses to this article can be read online at: http://www.ecologyandsociety.org/issues/responses. php/11814}

\section{Acknowledgments:}

Support for this paper was provided by The Netherlands Organization for Scientific Research (NWO), grant 824.15.022. We would like to thank Douglas Landis who provided helpful comments on an earlier draft of the manuscript. Lastly, we are grateful to the reviewers for their help in improving the manuscript.

\section{Data Availability Statement:}

The data that were derived from resources available in the public domain are available at: Great Britain Pesticide Usage Surveys: https://secure.fera.defra.gov.uk/pusstats/; Statistics Netherlands database: https:/lopendata.cbs.nllstatline/\#/CBS/en/; USA: USGS Pesticide National Synthesis Project: https://water.usgs.gov/ nawqalpnsp/usage/maps/county-levell

\section{LITERATURE CITED}

Alburaki, M., S. Boutin, P.-L. Mercier, Y. Loublier, M. Chagnon, and N. Derome. 2015. Neonicotinoid-coated Zea mays seeds indirectly affect honeybee performance and pathogen susceptibility in field trials. PLoS ONE 10(5):e0125790. https:// doi.org/10.1371/journal.pone.0125790

Barzman, M., P. Bàrberi, A. N. E. Birch, P. Boonekamp, S. Dachbrodt-Saaydeh, B. Graf, B. Hommel, J. E. Jensen, J. Kiss, P. Kudsk, J. R. Lamichhane, A. Messéan, A. C. Moonen, A. Ratnadass, P. Ricci, J. L. Sarah, and M. Sattin. 2015. Eight principles of integrated pest management. Agronomy for Sustainable Development 35(4):1199-1215. https://doi.org/10.1007/ $\underline{\text { s13593-015-0327-9 }}$

Bashir, Y. G. A., E. M. Elamin, and E. M. Elamin. 2003. Development and implementation of integrated pest management in the Sudan. Pages 131-143 in K. M. Maredia, D. Dakouo, and D. Mota-Sanchez, editors. Integrated pest management in the global arena. CAB International, Wallingford, UK. https://doi.org/10.1079/9780851996523.0131

Bass, C., I. Denholm, M. S. Williamson, and R. Nauen. 2015. The global status of insect resistance to neonicotinoid insecticides. Pesticide Biochemistry and Physiology 121:78-87. https://doi.org/10.1016/j.pestbp.2015.04.004

Bell, A., W. Zhang, and K. Nou. 2016. Pesticide use and cooperative management of natural enemy habitat in a framed field experiment. Agricultural Systems 143:1-13. https://doi. org/10.1016/j.agsy.2015.11.012

Berheim, E. H., J. A. Jenks, J. G. Lundgren, E. S. Michel, D. Grove, and W. F. Jensen. 2019. Effects of neonicotinoid insecticides on physiology and reproductive characteristics of captive female and fawn white-tailed deer. Scientific Reports 9:4534. https://doi. org/10.1038/s41598-019-40994-9

Bianchi, F. J. J. A., C. J. H. Booij, and T. Tscharntke. 2006. Sustainable pest regulation in agricultural landscapes: a review on landscape composition, biodiversity and natural pest control. Proceedings of the Royal Society B: Biological Sciences 273 (1595):1715-1727. https://doi.org/10.1098/rspb.2006.3530

Bianchi, F. J. J. A., A. R. Ives, and N. A. Schellhorn. 2013. Interactions between conventional and organic farming for biocontrol services across the landscape. Ecological Applications 23(7):1531-1543. https://doi.org/10.1890/12-1819.1

Blacquière, T., G. Smagghe, C. A. M. van Gestel, and V. Mommaerts. 2012. Neonicotinoids in bees: a review on concentrations, side-effects and risk assessment. Ecotoxicology 21:973-992. https://doi.org/10.1007/s10646-012-0863-X

Boccaletti, S., and M. Nardella. 2000. Consumer willingness to pay for pesticide-free fresh fruit and vegetables in Italy. International Food and Agribusiness Management Review 3 (3):297-310. https://doi.org/10.1016/S1096-7508(01)00049-0 
Bottrell, D. G., and K. G. Schoenly. 2012. Resurrecting the ghost of green revolutions past: the brown planthopper as a recurring threat to high-yielding rice production in tropical Asia. Journal of Asia-Pacific Entomology 15(1):122-140. https://doi.org/10.1016/ j.aspen.2011.09.004

Bowman, M. S., and D. Zilberman. 2013. Economic factors affecting diversified farming systems. Ecology and Society 18 (1):1-33. https://doi.org/10.5751/ES-05574-180133

Boyd, I. L. 2018. An inside view on pesticide policy. Nature Ecology and Evolution 2(6):920-921. https://doi.org/10.1038/ s41559-018-0557-8

Brühl, C. A., and J. G. Zaller. 2019. Biodiversity decline as a consequence of an inappropriate environmental risk assessment of pesticides. Frontiers in Environmental Science 7:177. https:// doi.org/10.3389/fenvs.2019.00177

Brust, G. E., and L. R. King. 1994. Effects of crop rotation and reduced chemical inputs on pests and predators in maize agroecosystems. Agriculture, Ecosystems and Environment 48 (1):77-89. https://doi.org/10.1016/0167-8809(94)90077-9

Busch, A. K., M. R. Douglas, G. M. Malcolm, H. D. Karsten, and J. F. Tooker. 2020. A high-diversity/IPM cropping system fosters beneficial arthropod populations, limits invertebrate pests, and produces competitive maize yields. Agriculture, Ecosystems and Environment 292:106812. https://doi.org/10.1016/j.agee.2019.106812

Byerlee, D., A. de Janvry, and E. Sadoulet. 2009. Agriculture for development: toward a new paradigm. Annual Review of Resource Economics 1:15-31. https://doi.org/10.1146/annurev. resource.050708.144239

Calvo-Agudo, M., J. González-Cabrera, Y. Picó, P. CalatayudVernich, A. Urbaneja, M. Dicke, and A. Tena. 2019. Neonicotinoids in excretion product of phloem-feeding insects kill beneficial insects. Proceedings of the National Academy of Sciences 116(34):16817-16822. https://doi.org/10.1073/pnas.1904298116

Castle, S. J. 1999. Agricultural intensification and pest outbreaks: a reappraisal of events in the Sudan Gezira. Annals of the Entomological Society of America 92(6):840-852. https://doi. org/10.1093/aesa/92.6.840

Chagnon, M., D. P. Kreutzweiser, E. A. D. Mitchell, C. A. Morrissey, D. A. Noome, and J. P. Van der Sluijs. 2015. Risks of large-scale use of systemic insecticides to ecosystem functioning and services. Environmental Science and Pollution Research 22:119-134. https://doi.org/10.1007/s11356-014-3277-x

Cimino, A. M., A. L. Boyles, K. A. Thayer, and M. J. Perry. 2017. Effects of neonicotinoid pesticide exposure on human health: a systematic review. Environmental Health Perspectives 125:155-162. https://doi.org/10.1289/EHP515

Clark, M., and D. Tilman. 2017. Comparative analysis of environmental impacts of agricultural production systems, agricultural input efficiency, and food choice. Environmental Research Letters 12:064016. https://doi.org/10.1088/1748-9326/ $\underline{\text { aa6cd5 }}$

Cowan, R., and P. Gunby. 1996. Sprayed to death: path dependence lock-in and pest control strategies. Economic Journal 106:521-542. https://doi.org/10.2307/2235561
Cowan, R., and S. Hultén. 1996. Escaping lock-in: the case of the electric vehicle. Technological Forecasting and Social Change 53:61-79. https://doi.org/10.1016/0040-1625(96)00059-5

DeBach, P. 1951. The necessity for an ecological approach to pest control on citrus in California. Journal of Economic Entomology 44(4):443-447. https://doi.org/10.1093/jee/44.4.443

Deguine, J.-P., P. Ferron, and D. Russell. 2008. Sustainable pest management for cotton production. A review. Agronomy for Sustainable Development 28:113-137. https://doi.org/10.1051/ agro:2007042

DiBartolomeis, M., S. Kegley, P. Mineau, R. Radford, and K. Klein. 2019. An assessment of acute insecticide toxicity loading (AITL) of chemical pesticides used on agricultural land in the United States. PLoS ONE 14(8):e0220029. https://doi. org/10.1371/journal.pone.0220029

Douglas, M. R., and J. F. Tooker. 2015. Large-scale deployment of seed treatments has driven rapid increase in use of neonicotinoid insecticides and preemptive pest management in U.S. field crops. Environmental Science and Technology 49:5088-5097. https://doi.org/10.1021/es506141g

Douglas, M. R., and J. F. Tooker. 2016. Meta-analysis reveals that seed-applied neonicotinoids and pyrethroids have similar negative effects on abundance of arthropod natural enemies. PeerJ 4:e2776. https://doi.org/10.7717/peerj.2776

Doutt, R. L., and R. F. Smith. 1971. The pesticide syndrome diagnosis and suggested prophylaxis. Pages 3-15 in C. B. Huffaker, editor. Biological control. Third edition. Plenum Press, New York, New York, USA. https://doi.org/10.1007/978-1-4615-6528-4 1

Dudley, N., S. J. Attwood, D. Goulson, D. Jarvis, Z. Pervez Bharucha, and J. Pretty. 2017. How should conservationists respond to pesticides as a driver of biodiversity loss in agroecosystems? Biological Conservation 209:449-453. https:// doi.org/10.1016/j.biocon.2017.03.012

Ekström, G., and B. Ekbom. 2011. Pest control in agroecosystems: an ecological approach. Critical Reviews in Plant Sciences 30(1-2):74-94. https://doi.org/10.1080/07352689.2011.554354

European Academies Science Advisory Council (EASAC). 2015. Ecosystem services, agriculture, and neonicotinoids. EASAC, Halle, Germany.

European Food Safety Authority (EFSA). 2018. Neonicotinoids: EFSA evaluates emergency uses. EFSA, Parma, Italy. [online] URL: https://www.efsa.europa.eu/en/press/news/180621

European Union (EU). 2018. Commission implementing regulation (EU) 2018/784 of 29 May 2018 amending implementing regulation (EU) No 540/2011 as regards the conditions of approval of the active substance clothianidin. Official Journal of the European Union L132:35.

Eveleens, K. G. 1983. Cotton-insect control in the Sudan Gezira: analysis of a crisis. Crop Protection 2:273-287. https://doi. org/10.1016/0261-2194(83)90002-9

Feder, G., R. E. Just, and D. Zilberman. 1985. Adoption of agricultural innovations in developing countries: a survey. Economic Development and Cultural Change 33(2):255-298. https://doi.org/10.1086/451461 
Fera. 2020. Pesticide usage survey reports. PUSSTATS application. Fera, Sand Hutton, UK. [online] URL: http:// pusstats.fera.defra.gov.uk/myindex.cfm

Flor, R. J., H. Maat, B. A. R. Hadi, V. Kumar, and N. Castilla. 2019. Do field-level practices of Cambodian farmers prompt a pesticide lock-in? Field Crops Research 235:68-78. https://doi. org/10.1016/j.fcr.2019.02.019

Foley, J. A., N. Ramankutty, K. A. Brauman, E. S. Cassidy, J. S. Gerber, M. Johnston, N. D. Mueller, C. O. Connell, D. K. Ray, P. C. West, C. Balzer, E. M. Bennett, S. R. Carpenter, J. Hill, C. Monfreda, S. Polasky, J. Rockström, J. Sheehan, S. Siebert, D. Tilman, and D. P. M. Zaks. 2011. Solutions for a cultivated planet. Nature 478:337-342. https://doi.org/10.1038/nature10452

Furlan, L., and D. Kreutzweiser. 2015. Alternatives to neonicotinoid insecticides for pest control: case studies in agriculture and forestry. Environmental Science and Pollution Research 22:135-147. https://doi.org/10.1007/s11356-014-3628-7

Furlan, L., A. Pozzebon, C. Duso, N. Simon-Delso, F. SánchezBayo, P. A. Marchand, F. Codato, M. Bijleveld van Lexmond, and J. M. Bonmatin. 2018. An update of the Worldwide Integrated Assessment (WIA) on systemic insecticides. Part 3: alternatives to systemic insecticides. Environmental Science and Pollution Research. https://doi.org/10.1007/s11356-017-1052-5

Ge, L., N. P. R. Anten, I. D. E. Van Dixhoorn, P. H. Feindt, K. Kramer, R. Leemans, M. P. M. Meuwissen, H. Spoolder, and W. Sukkel. 2016. Why we need resilience thinking to meet societal challenges in bio-based production systems. Current Opinion in Environmental Sustainability 23:17-27. https://doi.org/10.1016/j. cosust.2016.11.009

Giannakas, K., and M. Fulton. 2005. Process innovation activity in a mixed oligopoly: the role of cooperatives. American Journal of Agricultural Economics 87(2):406-422. https://doi.org/10.1111/ j.1467-8276.2005.00731.x

Gibbons, D. W., C. A. Morrissey, and P. Mineau. 2015. A review of the direct and indirect effects of neonicotinoids and fipronil on vertebrate wildlife. Environmental Science and Pollution Research 22(1):103-118. https://doi.org/10.1007/s11356-014-3180-5

Giorio, C., A. Safer, F. Sánchez-Bayo, A. Tapparo, A. Lentola, V. Girolami, M. Bijleveld van Lexmond, and J.-M. Bonmatin. 2017. An update of the Worldwide Integrated Assessment (WIA) on systemic insecticides. Part 1: new molecules, metabolism, fate, and transport. Environmental Science and Pollution Research. https://doi.org/10.1007/s11356-017-0394-3

Goulson, D. 2013. An overview of the environmental risks posed by neonicotinoid insecticides. Journal of Applied Ecology 50:977-987. https://doi.org/10.1111/1365-2664.12111

Goulson, D. 2018. Call to restrict neonicotinoids. Science 360 (6392).

Gross, K., and J. A. Rosenheim. 2011. Quantifying secondary pest outbreaks in cotton and their monetary cost with causal-inference statistics. Ecological Applications 21(7):2770-2780. https://doi. org/10.1890/11-0118.1

Hallmann, C. A., R. P. B. Foppen, C. A. M. van Turnhout, H. de Kroon, and E. Jongejans. 2014. Declines in insectivorous birds are associated with high neonicotinoid concentrations. Nature 511:341-343. https://doi.org/10.1038/nature13531

Hansen, M. 1988. Escape from the pesticide treadmill: alternatives to pesticides in developing countries. Institute for Consumer Policy Research, Mount Vernon, USA.

Hill, M. P., S. Macfadyen, and M. A. Nash. 2017. Broad spectrum pesticide application alters natural enemy communities and may facilitate secondary pest outbreaks. PeerJ 5:e4179. https://doi. org/10.7717/peerj.4179

Humann-Guilleminot, S., S. Clément, J. Desprat, Ł. J. Binkowski, G. Glauser, and F. Helfenstein. 2019. A large-scale survey of House Sparrows feathers reveals ubiquitous presence of neonicotinoids in farmlands. Science of the Total Environment 660:1091-1097. https://doi.org/10.1016/j.scitotenv.2019.01.068

Iost Filho, F. H., W. B. Heldens, Z. Kong, and E. S. de Lange. 2020. Drones: innovative technology for use in precision pest management. Journal of Economic Entomology 113(1):1-25. https://doi.org/10.1093/jee/toz268

Jactel, H., F. Verheggen, D. Thiéry, A. J. Escobar-Gutiérrez, E. Gachet, N. Desneux, and the Neonicotinoids Working Group. 2019. Alternatives to neonicotinoids. Environment International 129:423-429. https://doi.org/10.1016/j.envint.2019.04.045

Jeschke, P., R. Nauen, M. Schindler, and A. Elbert. 2011. Overview of the status and global strategy for neonicotinoids. Journal of Agricultural and Food Chemistry 59:2987-2908. https:// doi.org/10.1021/jf101303g

Jørgensen, P. S., A. Aktipis, Z. Brown, Y. Carrière, S. Downes, R. R. Dunn, G. Epstein, G. B. Frisvold, D. Hawthorne, Y. T. Gröhn, G. T. Gujar, D. Jasovský, E. Y. Klein, F. Klein, G. Lhermie, D. Mota-Sanchez, C. Omoto, M. Schlüter, H. M. Scott, D. Wernli, and S. P. Carroll. 2018. Antibiotic and pesticide susceptibility and the Anthropocene operating space. Nature Sustainability 1 (11):632-641. https://doi.org/10.1038/s41893-018-0164-3

Juma, C. 2016. Innovation and its enemies: Why people resist new technologies. Oxford University Press, Oxford, UK. https://doi. org/10.1093/acprof:oso/9780190467036.001.0001

Kallis, G., and R. B. Norgaard. 2010. Coevolutionary ecological economics. Ecological Economics 69:690-699. https://doi. org/10.1016/j.ecolecon.2009.09.017

Karp, D. S., R. Chaplin-Kramer, T. D. Meehan, E. A. Martin, F. DeClerck, H. Grab, C. Gratton, L. Hunt, A. E. Larsen, A. Martínez-Salinas, M. E. O'Rourke, A. Rusch, K. Poveda, M. Jonsson, J. A. Rosenheim, N. A. Schellhorn, T. Tscharntke, S. D. Wratten, W. Zhang, A. L. Iverson, L. S. Adler, M. Albrecht, A. Alignier, G. M. Angelella, M. Z. Anjum, J. Avelino, P. Batáry, J. M. Baveco, F. J. J. A. Bianchi, K. Birkhofer, E. W. Bohnenblust, R. Bommarco, M. J. Brewer, B. Caballero-López, Y. Carrière, L. G. Carvalheiro, L. Cayuela, M. Centrella, A. Ćetković, D. C. Henri, A. Chabert, A. C. Costamagna, A. De la Mora, J. de Kraker, N. Desneux, E. Diehl, T. Diekötter, C. F. Dormann, J. O. Eckberg, M. H. Entling, D. Fiedler, P. Franck, F. J. F. van Veen, T. Frank, V. Gagic, M. P. D. Garratt, A. Getachew, D. J. Gonthier, P. B. Goodell, I. Graziosi, R. L. Groves, G. M. Gurr, Z. HajianForooshani, G. E. Heimpel, J. D. Herrmann, A. S. Huseth, D. J. Inclán, A. J. Ingrao, P. Iv, K. Jacot, G. A. Johnson, L. Jones, M. 
Kaiser, J. M. Kaser, T. Keasar, T. N. Kim, M. Kishinevsky, D. A. Landis, B. Lavandero, C. Lavigne, A. Le Ralec, D. Lemessa, D. K. Letourneau, H. Liere, Y. Lu, Y. Lubin, T. Luttermoser, B. Maas, K. Mace, F. Madeira, V. Mader, A. M. Cortesero, L. Marini, E. Martinez, H. M. Martinson, P. Menozzi, M. G. E. Mitchell, T. Miyashita, G. A. R. Molina, M. A. MolinaMontenegro, M. E. O'Neal, I. Opatovsky, S. Ortiz-Martinez, M. Nash, Ö. Östman, A. Ouin, D. Pak, D. Paredes, S. Parsa, H. Parry, R. Perez-Alvarez, D. J. Perović, J. A. Peterson, S. Petit, S. M. Philpott, M. Plantegenest, M. Plećas, T. Pluess, X. Pons, S. G. Potts, R. F. Pywell, D. W. Ragsdale, T. A. Rand, L. Raymond, B. Ricci, C. Sargent, J. P. Sarthou, J. Saulais, J. Schäckermann, N. P. Schmidt, G. Schneider, C. Schüepp, F. S. Sivakoff, H. G. Smith, K. S. Whitney, S. Stutz, Z. Szendrei, M. B. Takada, H. Taki, G. Tamburini, L. J. Thomson, Y. Tricault, N. Tsafack, M. Tschumi, M. Valantin-Morison, M. van Trinh, W. van der Werf, K. T. Vierling, B. P. Werling, J. B. Wickens, V. J. Wickens, B. A. Woodcock, K. Wyckhuys, H. Xiao, M. Yasuda, A. Yoshioka, and Y. Zou. 2018. Crop pests and predators exhibit inconsistent responses to surrounding landscape composition. Proceedings of the National Academy of Sciences of the United States of America 115(33):E7863-E7870. https://doi.org/10.1073/pnas.1800042115

Kinzig, A. P., P. Ryan, M. Etienne, H. Allison, T. Elmqvist, and B. H. Walter. 2006. Resilience and regime shifts: assessing cascading effects. Ecology and Society 11(1):20. https://doi. org/10.5751/ES-01678-110120

Kline, D. 2001. Positive feedback, lock-in, and environmental policy. Policy Sciences 34:95-107. https://doi.org/10.1023/ A:1010357309367

Krupke, C. H., J. D. Holland, E. Y. Long, and B. D. Eitzer. 2017. Planting of neonicotinoid-treated maize poses risks for honey bees and other non-target organisms over a wide area without consistent crop yield benefit. Journal of Applied Ecology 54:1449-1458. https://doi.org/10.1111/1365-2664.12924

Labarthe, P. 2009. Extension services and multifunctional agriculture. Lessons learnt from the French and Dutch contexts and approaches. Journal of Environmental Management 90 (SUPPL. 2):S193-S202. https://doi.org/10.1016/j.jenvman.2008.11.021

LaCanne, C. E., and J. G. Lundgren. 2018. Regenerative agriculture: merging farming and natural resource conservation profitably. PeerJ 6:e4428. https://doi.org/10.7717/peerj.4428

Lamichhane, J. R., S. Dachbrodt-Saaydeh, P. Kudsk, and A. Messéan. 2016. Toward a reduced reliance on conventional pesticides in European agriculture. Plant Disease 100(1):10-24. https://doi.org/10.1094/pdis-05-15-0574-fe

Lamine, C. 2011. Transition pathways towards a robust ecologization of agriculture and the need for system redesign. Cases from organic farming and IPM. Journal of Rural Studies 27:209-219. https://doi.org/10.1016/j.jrurstud.2011.02.001

Lamine, C., M. Barbier, J. Blanc, J. Buurma, I. Haynes, J. Lehota, E. Maraccini, N. Egon, R. Paratte, Z. Szabo, and A. Wierzbicka. 2010. Reducing the dependence on pesticides: a matter of transitions within the whole agri-food system. Pages 1943-1954 in Transitions towards sustainable agriculture: from farmers to agro-food system. 9th European IFSA Symposium, Vienna, Austria.
Lamprinopoulou, C., A. Renwick, L. Klerkx, F. Hermans, and D. Roep. 2014. Application of an integrated systemic framework for analysing agricultural innovation systems and informing innovation policies: comparing the Dutch and Scottish agrifood sectors. Agricultural Systems 129:40-54. https://doi.org/10.1016/ j.agsy.2014.05.001

Letourneau, D. K. 2012. Integrated pest management - outbreaks prevented, delayed, or facilitated? Pages 371-394 in P. Barbosa, D. K. Letourneau, and A. A. Agrawal, editors. Insect outbreaks revisited. Blackwell, Hoboken, New Jersey, USA. https://doi. org/10.1002/9781118295205.ch18

Letourneau, D. K., S. G. Bothwell Allen, and J. O. Stireman III. 2012. Perennial habitat fragments, parasitoid diversity and parasitism in ephemeral crops. Journal of Applied Ecology 49 (6):1405-1416. https://doi.org/10.1111/1365-2664.12001

Lewis, W. J., J. C. Van Lenteren, S. C. Phatak, and J. H. Tumlinson III. 1997. A total system approach to sustainable pest management. Proceedings of the National Academy of Sciences of the United States of America 94(23):12243-12248. https://doi. org/10.1073/pnas.94.23.12243

Liebowitz, S. J., and S. E. Margolis. 1995. Path dependence, lockin, and history. Journal of Law, Economics \& Organization 11:205-226. https://doi.org/10.2139/ssrn.1706450

Liu, B., L. Yang, F. Yang, Q. Wang, Y. Yang, Y. Lu, and M. M. Gardiner. 2016. Landscape diversity enhances parasitism of cotton bollworm (Helicoverpa armigera) eggs by Trichogramma chilonis in cotton. Biological Control 93:15-23. https://doi. org/10.1016/j.biocontrol.2015.11.004

Lundgren, J. G., and S. W. Fausti. 2015. Trading biodiversity for pest problems. Science Advances 1(6):e1500558. https://doi. org/10.1126/sciadv. 1500558

Macfadyen, S., J. M. Tylianakis, D. K. Letourneau, T. G. Benton, P. Tittonell, M. P. Perring, C. Gómez-Creutzberg, A. Báldi, J. M. Holland, L. Broadhurst, K. Okabe, A. R. Renwick, B. GemmillHerren, and H. G. Smith. 2015. The role of food retailers in improving resilience in global food supply. Global Food Security 7:1-8. https://doi.org/10.1016/j.gfs.2016.01.001

MacMillan, T., and T. G. Benton. 2014. Agriculture: engage farmers in research. Nature 509:25-27. https://doi.org/10.1038/509025a

Magrini, M. B., M. Anton, C. Cholez, G. Corre-Hellou, G. Duc, M.-H. Jeuffroy, J.-M. Meynard, E. Pelzer, A.-S. Voisin, and S. Walrand. 2016. Why are grain-legumes rarely present in cropping systems despite their environmental and nutritional benefits? Analyzing lock-in in the French agrifood system. Ecological Economics 126:152-162. https://doi.org/10.1016/j.ecolecon.2016.03.024

Matteson, P. C. 2000. Insect pest management in tropical asian irrigated rice. Annual Review of Entomology(45):549-574. https:// doi.org/10.1146/annurev.ento.45.1.549

Meehan, T. D., C. Gratton, E. Diehl, N. D. Hunt, D. F. Mooney, S. J. Ventura, B. L. Barham, and R. D. Jackson. 2013. Ecosystemservice tradeoffs associated with switching from annual to perennial energy crops in Riparian zones of the U.S. Midwest. PLoS ONE 8(11):e80093. https://doi.org/10.1371/journal. pone. 0080093 
Meehan, T. D., B. P. Werling, D. A. Landis, and C. Gratton. 2011. Agricultural landscape simplification and insecticide use in the Midwestern United States. Proceedings of the National Academy of Sciences of the United States of America 108:11500-11505. https://doi.org/10.1073/pnas.1100751108

Milner, A. M., and I. L. Boyd. 2017. Toward pesticidovigilance. Science 357(6357):1232-1234. https://doi.org/10.1126/science. $\underline{\operatorname{aan} 2683}$

Mitchell, E. A. D., B. Mulhauser, M. Mulot, A. Mutabazi, G. Glauser, and A. Aebi. 2017. A worldwide survey of neonicotinoids in honey. Science 358(6359):109-111. https://doi. org/10.1126/science.aan3684

Mogren, C. L., and J. G. Lundgren. 2016. Neonicotinoidcontaminated pollinator strips adjacent to cropland reduce honey bee nutritional status. Scientific Reports 6:29608. https://doi. org/10.1038/srep29608

Morrissey, J. E., M. Mirosa, and M. Abbott. 2014. Identifying transition capacity for agri-food regimes: application of the multilevel perspective for strategic mapping. Journal of Environmental Policy \& Planning 16:281-301. https://doi.org/10.1080/1523908X$\underline{.2013 .845521}$

Mota-Sanchez, D., and J. C. Wise. 2020. Arthropod pesticide resistance database. [online] URL: http://www.pesticideresistance. org

Mourtzinis, S., C. H. Krupke, P. D. Esker, A. Varenhorst, N. J. Arneson, C. A. Bradley, A. M. Byrne, M. I. Chilvers, L. J. Giesler, A. Herbert, Y. R. Kandel, M. J. Kazula, C. Hunt, L. E. Lindsey, S. Malone, D. S. Mueller, S. Naeve, E. Nafziger, D. D. Reisig, W. J. Ross, D. R. Rossman, S. Taylor, and S. P. Conley. 2019. Neonicotinoid seed treatments of soybean provide negligible benefits to U.S. farmers. Scientific Reports 9:11207. https://doi. org/10.1038/s41598-019-47442-8

Murray, D. L. 1994. Cultivating crisis: the human cost of pesticides in Latin America. University of Texas Press, Austin, Texas, USA.

Myers, C., and E. Hill. 2014. Benefits of neonicotinoid seed treatments to soybean production. United States Environmental Protection Agency, Washington, D.C., USA.

Naranjo, S. E., and P. C. Ellsworth. 2009. Fifty years of the integrated control concept: moving the model and implementation forward in Arizona. Pest Management Science 65(12):1267-1286. https://doi.org/10.1002/ps.1861

Nauen, R., and I. Denholm. 2005. Resistance of insect pests to neonicotinoid insecticides: current status and future prospects. Archives of Insect Biochemistry and Physiology 58(4):200-215. https://doi.org/10.1002/arch.20043

Norgaard, R. B. 1976. The economics of improving pesticide use. Annual Review of Entomology 21:45-60. https://doi.org/10.1146/ annurev.en.21.010176.000401

Oka, I. N. 1991. Success and challenges of the Indonesia National Integrated Pest Management Program in the rice-based cropping system. Crop Protection 10:163-165. https://doi.org/10.1016/0261-2194 (91) $90037-\mathrm{R}$
Oreskes, N., and E. M. Conway. 2011. Merchants of doubt: How a handful of scientists obscured the truth on issues from tobacco smoke to global warming. Bloomsbury, London, UK.

Orr, A. 2003. Integrated pest management for resource-poor African farmers: Is the emperor naked? World Development 31 (5):831-845. https://doi.org/10.1016/s0305-750x(03)00015-9

Pardey, P. G., J. M. Alston, and V. W. Ruttan. 2010. The economics of innovation and technical change in agriculture. Pages 939-984 in B. H. Hall and N. Rosenberg, editors. Handbook of the economics of innovation. Elsevier B.V., Amsterdam, The Netherlands. https://doi.org/10.1016/S0169-7218(10)02006-X

Parsa, S., S. Morse, A. Bonifacio, T. C. B. Chancellor, B. Condori, V. Crespo-Pérez, S. L. A. Hobbs, J. Kroschel, M. N. Ba, F. Rebaudo, S. G. Sherwood, S. J. Vanek, E. Faye, M. A. Herrera, and O. Dangles. 2014. Obstacles to integrated pest management adoption in developing countries. Proceedings of the National Academy of Sciences of the United States of America 111 (10):3889-3894. https://doi.org/10.1073/pnas.1312693111

Perkins, R. 2003. Technological 'lock-in.' Pages 1-8 in E. Neumayer, editor. Online encyclopaedia of ecological economics. The International Society for Ecological Economics.

Pimentel, D., E. C. Terhune, W. Dritschilo, D. Gallahan, N. Kinner, D. Nafus, R. Peterson, N. Zareh, J. Misiti, and O. HaberSchaim. 1977. Pesticides, insects in foods, and cosmetic standards. BioScience 27(3):178-185. https://doi.org/10.2307/1297579

Pisa, L., D. Goulson, E.-C. Yang, D. Gibbons, F. Sánchez-Bayo, E. Mitchell, A. Aebi, J. van der Sluijs, C. J. K. MacQuarrie, C. Giorio, E. Yim Long, M. McField, M. Bijleveld van Lexmond, and J.-M. Bonmatin. 2017. An update of the Worldwide Integrated Assessment (WIA) on systemic insecticides. Part 2: impacts on organisms and ecosystems. Environmental Science and Pollution Research. https://doi.org/10.1007/s11356-017-0341-3

Pisa, L. W., V. Amaral-Rogers, L. P. Belzunces, J. M. Bonmatin, C. A. Downs, D. Goulson, D. P. Kreutzweiser, C. Krupke, M. Liess, M. McField, C. A. Morrissey, D. A. Noome, J. Settele, N. Simon-Delso, J. D. Stark, J. P. Van der Sluijs, H. Van Dyck, and M. Wiemers. 2015. Effects of neonicotinoids and fipronil on nontarget invertebrates. Environmental Science and Pollution Research 22:68-102. https://doi.org/10.1007/s11356-014-3471-x

Popp, J., K. Pető, and J. Nagy. 2013. Pesticide productivity and food security. A review. Agronomy for Sustainable Development 33(1):243-255. https://doi.org/10.1007/s13593-012-0105-x

Pretty, J. 2018. Intensification for redesigned and sustainable agricultural systems. Science 362(6417). https://doi.org/10.1126/ $\underline{\text { science.aav0294 }}$

Roubos, C. R., C. Rodriguez-Saona, and R. Isaacs. 2014. Mitigating the effects of insecticides on arthropod biological control at field and landscape scales. Biological Control 75:28-38. https://doi.org/10.1016/j.biocontrol.2014.01.006

Rundlöf, M., G. K. S. Andersson, R. Bommarco, I. Fries, V. Hederström, L. Herbertsson, O. Jonsson, B. K. Klatt, T. R. Pedersen, J. Yourstone, and H. G. Smith. 2015. Seed coating with a neonicotinoid insecticide negatively affects wild bees. Nature 521:77-80. https://doi.org/10.1038/nature14420 
Ruttan, V. W. 1996. Induced innovation and path dependence: a reassessment with respect to agricultural development and the environment. Technological Forecasting and Social Change 53 (1):41-59. https://doi.org/10.1016/0040-1625(96)00055-8

Savary, S., F. Horgan, L. Willocquet, and K. L. Heong. 2012. A review of principles for sustainable pest management in rice. Crop Protection 32:54-63. https://doi.org/10.1016/j.cropro.2011.10.012

Schellhorn, N. A., F. J. J. A. Bianchi, and C. L. Hsu. 2014. Movement of entomophagous arthropods in agricultural landscapes: links to pest suppression. Annual Review of Entomology 59(1):559-581. https://doi.org/10.1146/annurevento-011613-161952

Schellhorn, N. A., S. Macfadyen, F. J. J. A. Bianchi, D. G. Williams, and M. P. Zalucki. 2008. Managing ecosystem services in broadacre landscapes: What are the appropriate spatial scales? Australian Journal of Experimental Agriculture 48(12):1549-1559. https://doi.org/10.1071/ea08112

Schut, M., J. Rodenburg, L. Klerkx, A. van Ast, and L. Bastiaans. 2014. Systems approaches to innovation in crop protection. A systematic literature review. Crop Protection 56:98-108. https:// doi.org/10.1016/j.cropro.2013.11.017

Seagraves, M. P., and J. G. Lundgren. 2012. Effects of neonicitinoid seed treatments on soybean aphid and its natural enemies. Journal of Pest Science 85:125-132. https://doi. org/10.1007/s10340-011-0374-1

Settle, W. H., H. Ariawan, E. T. Astuti, W. Cahyana, A. L. Hakim, D. Hindayana, and A. S. Lestari. 1996. Managing tropical rice pests through conservation of generalist natural enemies and alternative prey. Ecology 77:1975-1988. https://doi.org/10.2307/2265694

Sigsgaard, L. 2000. Early season natural biological control of insect pests in rice by spiders - and some factors in the management of the cropping system that may affect this control. European Arachnology 2000:57-64.

Simon-Delso, N., V. Amaral-Rogers, L. P. Belzunces, J.-M. Bonmatin, M. Chagnon, C. Downs, L. Furlan, D. W. Gibbons, C. Giorio, V. Girolami, D. Goulson, D. P. Kreutzweiser, C. Krupke, M. Liess, E. Long, M. Mcfield, P. Mineau, E. A. D. Mitchell, C. A. Morrissey, D. A. Noome, L. Pisa, J. Settele, J. D. Stark, A. Tapparo, H. Van Dyck, J. Van Praagh, J. P. Van Der Sluijs, P. R. Whitehorn, and M. Wiemers. 2015. Systemic insecticides (neonicotinoids and fipronil): trends, uses, mode of action and metabolites. Environmental Science and Pollution Research 22:5-34. https://doi.org/10.1007/s11356-014-3470-y

Sparks, T. C., and B. A. Lorsbach. 2017. Agrochemical discovery - building the next generation of insect control agents. Pages 1-17 in A. D. Gross, Y. Ozoe, and J. R. Coats, editors. Advances in agrochemicals: ion channels and $G$ protein-coupled receptors (GPCRs) as targets for pest control. American Chemical Society, Washington, D.C., USA. https://doi.org/10.1021/bk-2017-1264. $\underline{\mathrm{ch} 001}$

Sponsler, D. B., C. M. Grozinger, C. Hitaj, M. Rundlöf, C. Botías, A. Code, E. V. Lonsdorf, A. P. Melathopoulos, D. J. Smith, S. Suryanarayanan, W. E. Thogmartin, N. M. Williams, M. Zhang, and M. R. Douglas. 2019. Pesticides and pollinators: a socioecological synthesis. Science of the Total Environment 662:1012-1027. https://doi.org/10.1016/j.scitotenv.2019.01.016
Stam, P. A., A. A. Abdelrahman, and B. Munir. 1994. Comparisons of control action thresholds for Heliothis armigera, Bemisia tabaci and Aphis gossypii on cotton in the Sudan Gezira and Rahad regions. Crop Protection 13:503-512. https://doi. org/10.1016/0261-2194(94)90102-3

State of Maryland. 2016. Neonicotinoid pesticides - restrictions on sales and use (Pollinator protection act of 2016). General Assembly of Maryland, Annapolis, Maryland, USA.

Statline. 2019. Use of crop protection products in agriculure [Translated from the Dutch: Gebruik gewasbeschermingsmiddelen in de landbouw]. Statistics Netherlands' Database (CBS), The Hague, The Netherlands. [online] URL: https://opendata.cbs.nl/ statline/\#/CBS/n1/

Swezey, S. L., D. L. Murray, and R. G. Daxl. 1986. Nicaragua's revolution in pesticide policy. Environment: Science and Policy for Sustainable Development 28:6-36. https://doi.org/10.1080/00139$\underline{157.1986 .9929866}$

Thorburn, C. 2015. The rise and demise of integrated pest management in rice in Indonesia. Insects 6(2):381-408. https:// doi.org/10.3390/insects6020381

Thrupp, L. A. 1988. Pesticides and policies: approaches to pestcontrol dilemmas in Nicaragua and Costa Rica. Latin American Perspectives 15(4):37-70. https://doi.org/10.1177/0094582X8801500403

Thrupp, L. A. 1990. Entrapment and escape from fruitless insecticide use: lessons from the banana sector of Costa Rica. International Journal of Environmental Studies 36:173-189. https://doi.org/10.1080/00207239008710594

Tooker, J. F., M. R. Douglas, and C. H. Krupke. 2017. Neonicotinoid seed treatments: limitations and compatibility with integrated pest management. Agriculture \& Environmental Letters 2(1):1-5. https://doi.org/10.2134/ael2017.08.0026

Tscharntke, T., R. Bommarco, Y. Clough, T. O. Crist, D. Kleijn, T. A. Rand, J. M. Tylianakis, S. van Nouhuys, and S. Vidal. 2007. Conservation biological control and enemy diversity on a landscape scale. Biological Control 43(3):294-309. https://doi. org/10.1016/j.biocontrol.2007.08.006

Turnbull, L., and A. Hector. 2010. How to get even with pests. Nature 466:36-37. https://doi.org/10.1038/466036a

U.S. Environmental Protection Agency (EPA). 2020. Schedule for review of reonicotinoid pesticides. U.S. EPA, Washington, D.C., USA. [online] URL: https://www.epa.gov/pollinator-protection/ schedule-review-neonicotinoid-pesticide

U.S.Geological Survey (USGS). 2019. U.S.Geological Survey National Water-Quality Assessment (NAWQA) Project: The pesticidenational synthesis project. USGS, Reston, Virginia, USA. [online] URL: https://water.usgs.gov/nawqa/pnsp/usage/maps/

Van den Berg, H., and J. Jiggins. 2007. Investing in farmers - the impacts of farmer field schools in relation to integrated pest management. World Development 35:663-686. https://doi. org/10.1016/j.worlddev.2006.05.004

van den Bosch, R. 1989. The pesticide conspiracy. First edition. University of California Press, Berkeley, California, USA.

van Lenteren, J. C., K. Bolckmans, J. Köhl, W. J. Ravensberg, and A. Urbaneja. 2018. Biological control using invertebrates and 
microorganisms: plenty of new opportunities. BioControl 63 (1):39-59. https://doi.org/10.1007/s10526-017-9801-4

Vandermeer, J. 1991. Environmental problems arising from national revolutions in the Third World: the case of Nicaragua. Social Text 28:39-45. https://doi.org/10.2307/466374

Vandermeer, J., and D. A. Andow. 1986. Prophylactic and responsive components of an integrated pest management program. Journal of Economic Entomology 79(2):299-302. https:// doi.org/10.1093/jee/79.2.299

Vanloqueren, G., and P. V. Baret. 2009. How agricultural research systems shape a technological regime that develops genetic engineering but locks out agroecological innovations. Research Policy 38:971-983. https://doi.org/10.1016/j.respol.2009.02.008

Whalon, M. E., D. Mota-Sanchez, and R. M. Hollingworth. 2008. Analysis of global pesticide resistance in arthropods. Pages 5-31 in M. E. Whalon, D. Mota-Sanchez, and R. M. Hollingworth, editors. Global pesticide resistance in arthropods. CABI, Wallingford, UK. https://doi.org/10.1079/9781845933531.0005

Whitehorn, P. R., S. O'Connor, F. L. Wackers, and D. Goulson. 2012. Neonicotinoid pesticide reduces bumble bee colony growth and queen production. Science 336:351-352. https://doi. org/10.1126/science.1215025

Wiedenmann, R. N., and J. W. Smith. 1997. Attributes of natural enemies in ephemeral crop habitats. Biological Control 10 (1):16-22. https://doi.org/10.1006/bcon.1997.0544

Wilson, C., and C. Tisdell. 2001. Why farmers continue to use pesticides despite environmental, health and sustainability costs. Ecological Economics 39(3):449-462. https://doi.org/10.1016/ $\underline{\mathrm{S} 0921-8009(01) 00238-5}$

Woodcock, B. A., N. J. B. Isaac, J. M. Bullock, D. B. Roy, D. G. Garthwaite, A. Crowe, and R. F. Pywell. 2016. Impacts of neonicotinoid use on long-term population changes in wild bees in England. Nature Communications 7:12459. https://doi. org/10.1038/ncomms12459

Wyckhuys, K. A. G., J. W. Bentley, R. Lie, L. T. P. Nghiem, and M. Fredrix. 2018. Maximizing farm-level uptake and diffusion of biological control innovations in today's digital era. BioControl 63(1):133-148. https://doi.org/10.1007/s10526-017-9820-1

Wyckhuys, K. A. G., K. L. Heong, F. Sanchez-Bayo, F. J. J. A. Bianchi, J. G. Lundgren, and J. W. Bentley. 2019. Ecological illiteracy can deepen farmers' pesticide dependency. Environmental Research Letters 14:9. https://doi.org/10.1088/1748-9326/ab34c9

Yletyinen, J., P. Brown, R. Pech, D. Hodges, P. E. Hulme, T. F. Malcolm, F. J. F. Maseyk, D. A. Peltzer, G. L. W. Perry, S. J. Richardson, S. J. Smaill, M. C. Stanley, J. H. Todd, P. J. Walsh, W. Wright, and J. M. Tylianakis. 2019. Understanding and managing social-ecological tipping points in primary industries. BioScience 69(5):335-347. https://doi.org/10.1093/biosci/biz031

Zalucki, M. P., D. Adamson, and M. J. Furlong. 2009. The future of IPM: whither or wither? Australian Journal of Entomology 48 (2):85-96. https://doi.org/10.1111/j.1440-6055.2009.00690.x
Zimmermann, J., and J. C. Stout. 2016. Underestimating neonicotinoid exposure: how extent and magnitude may be affected by land-use change. Environmental Science and Pollution Research 23:7050-7054. https://doi.org/10.1007/s11356-016-6159-6 


\section{Appendix 1}

\section{Case study USA}

Subsistence \& exploitation

During the 1940s, the USA government policies incentivized the uptake of high yielding crop varieties to enhance agricultural productivity. Cotton growers in southern Texas readily switched to these high yielding cotton varieties that were susceptible to insect attack (e.g. boll weevil, $A$. grandis), which made growers extremely reliant on the use of pesticides (Fig. A1.1). Growers lowered their pest damage thresholds in cotton, reinforcing the adoption of chemical pesticides (Cowan and Gunby 1996). By the mid-1950s key pests of cotton ( $A$. grandis, cotton fleahopper (Pseudatomoscelis seriatus) and pink bollworm (Pectinophora gossypiella)) had developed resistance to frequently applied insecticides (e.g. DDT, dieldrin). As a response, new mixtures of insecticides were introduced, and dosages and application frequencies increased.

\section{Crisis \& disaster}

The response to pest outbreaks resulted in initial effective control of key pests, but stimulated a resurgence of secondary pests, which became key pests. By 1968 almost 200,000 ha of cotton was grown in Texas (Adkisson et al. 1982). Secondary pests developed resistance against all insecticides used and inflicted severe damage to cotton, causing complete crop failure, and resulting in a shrinking of the cotton production area in Texas to 64,000 ha in 1975 (Adkisson et al. 1982, Cowan and Gunby 1996).

In the 'rest of Texas' (Fig. A1.1B) and the area of Trans-Pecos (Fig. A1.1C) new insecticides (organophosphates) were introduced as a response to resistance development to organochlorines, and dosages and application frequencies increased. This response resulted in effective suppression of key pests, but stimulated a resurgence of secondary pests $(H$. zea, tobacco budworm (Heliothis virescens) and cabbage looper (Trichoplusia ni)), which in turn became key pests (Adkisson et al. 1982, Cowan and Gunby 1996). In the 'rest of Texas' (Fig. A1.1B), at the end of the 1960s, cotton pests, such as $A$. grandis, $P$. seriatus and $P$. gossypiella, were not controlled by organophosphates due to resistance. In the Trans-Pecos area (Fig. A1.1C) cotton growers continued using pesticides, because they thought the alternative was too complex and pesticides were simple to use based on calendar applications or signs of crop damage. Uncertainty about the efficacy of IPM contained growers locked-in in a pesticide dependent state (Cowan and Gunby 1996).

\section{Escape \& reorganization}

In response to insecticide resistance alternative paths were explored by cotton growers in Texas. Cotton growers on the High Plains of Texas (Fig. A1.1A) were quickly returning to IPM practices. In a coordinated effort to control pests, cotton growers in this area applied uniform delayed planting of cotton, limiting the need to use insecticides. Cotton growers in 'the rest of Texas' (Fig. A1.1B) also switched back to IPM as a pest management method, but switching costs were alleviated by government extension programs and state legislation was implemented to coordinate the adherence of farmers to a short growing season (Cowan and Gunby 1996). This addresses the importance of coordination efforts to overcome 'excess inertia' - the willingness to adopt a new technology knowing other will adopt the technology as well. Despite these efforts only a small group of farmers in Trans-Pecos switched to IPM 
(Fig. A1.1C), which was attributed to a lack of coordination mechanisms in overcoming the lock-in (Adkisson et al. 1982, Cowan and Gunby 1996).

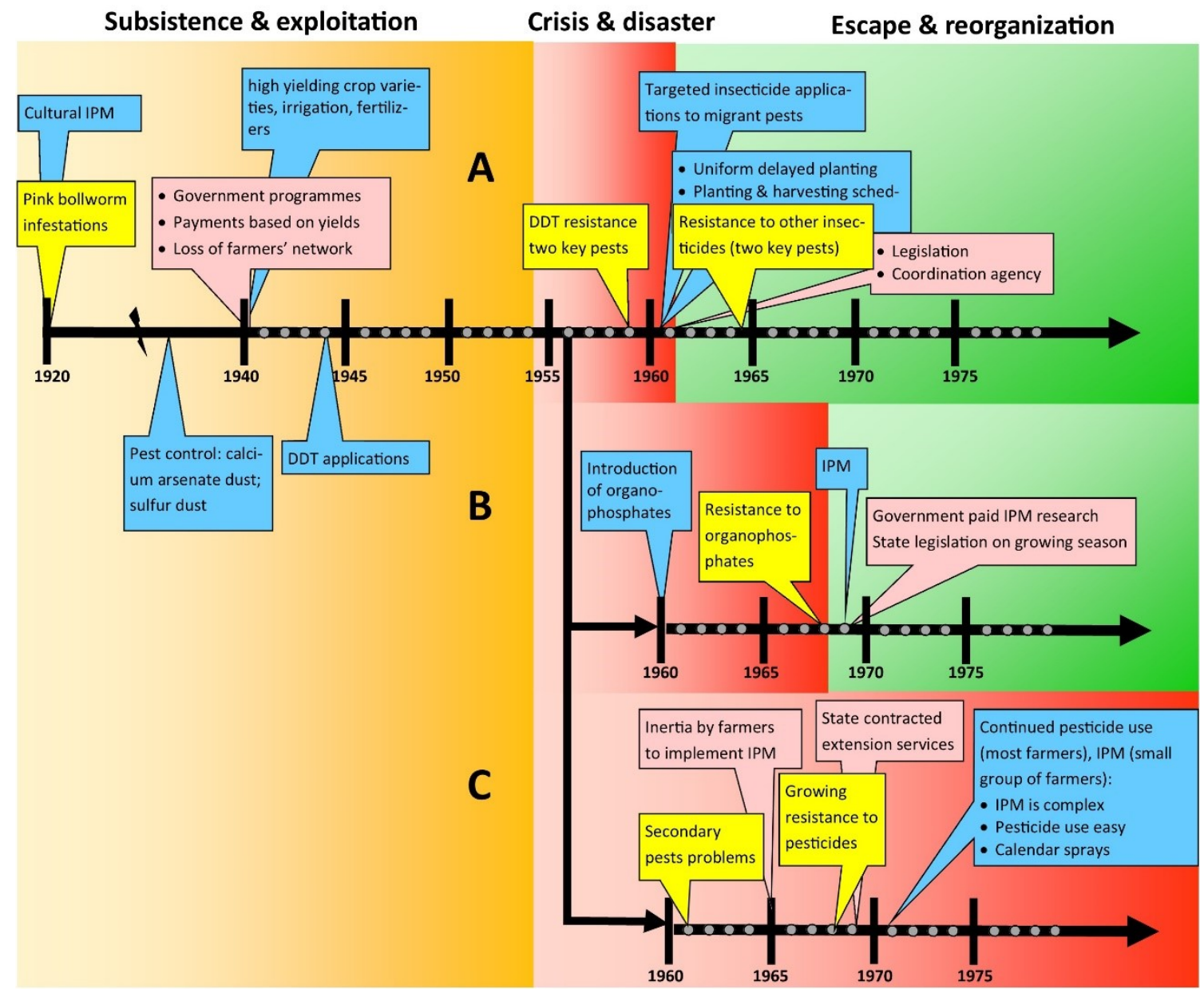

Figure A1.1: Timeline representing enabling and disabling drivers (text balloons) of pesticide use in cotton production in Texas, USA from 1920-1980. Colours referring to domains in the framework: farming (yellow), agro-landscapes (green), science \& technology (blue), and society (pink). The colours in the background (orange-red-green) indicate the transition to a new phase of the treadmill.

\section{Case study Costa Rica}

Subsistence \& exploitation

The pest management dynamics in banana production in the Golfito zone in Costa Rica (Fig. A1.2) provides another case study of interactions within the framework driving the pesticide treadmill. Thrupp (1990) portrays how a combination of ecological and socio-political drivers resulted in overuse of broad-spectrum pesticides, leading to insecticide resistance and secondary pests. A pesticide treadmill was initiated with calendar-scheduled applications of dieldrin against red rust thrips (Chaetanophothrips orchidii) and the banana corn weevil (Cosmopolites sordidus), which caused a resurgence of a secondary pest banana stalk borer (Castniomera humbolti) and the platynota moth (Platynota rostrana) (Stephens 1984, Thrupp 1990). 


\section{Crisis \& disaster}

Despite heavy spraying with organochlorine insecticides (dieldrin, DDT, endrin and heptachlor) and malathion and diazinon, these pests were not controlled, and by the late 1960s high economic losses undermined profits (Thrupp 1990). The pressure to fulfil production goals, maximizing yields and comply with aesthetic quality standards led to high risk attitude among managers of banana plantations and resulted in a high-input response to control pests (Thrupp 1990). To control resistant insects by 1960, dieldrin was replaced by carbaryl to control insect defoliators and the banana moth (Antichloris viridis), and toxaphene was used for control of West Indian Bagworm (Oiketicus kirbyi). By 1962 banana moths and corn weevils had developed resistance against dieldrin, but heavy spraying continued. There was an information gap regarding pesticide resistance, resurgence and secondary outbreaks, and the agrochemical industry was the most dominant source of information and publicity on pest control from 1950-1980. When resistance problems arose, industry advised banana plantation managers to switch to new insecticides. Although additional sources of information (e.g. government agencies or scientific journals) were consulted, they were given little attention. Risk perception of the managers was mainly shaped by production goals, information from the agrochemical industry and their fear of pests, which refrained managers from adopting alternative methods or approaches (Thrupp 1990). For example, even though it was already demonstrated in 1965 that banana plants could tolerate some defoliation, it took another thirteen years before a damage threshold level was adopted that took this into account (Stephens 1984). While field staff was well positioned to make informed location-specific decisions on pest management, the top-down centralized decision making on pest management did not allow this (Thrupp 1990).

\section{Escape \& reorganization}

The overuse of insecticides in banana production in Costa Rica (Fig. A1.2) began to undermine profits in the early 1970s. Combined with an increased awareness of the pest problem this led to an increase in economic damage threshold levels. After raising this threshold, insecticide use began to decrease gradually. However, a successful change in insect control was initiated in 1973 with a total ban on all insecticides. This allowed for the reestablishment of natural enemies and within two years insect pests nearly disappeared (Stephens 1984, Thrupp 1990). 


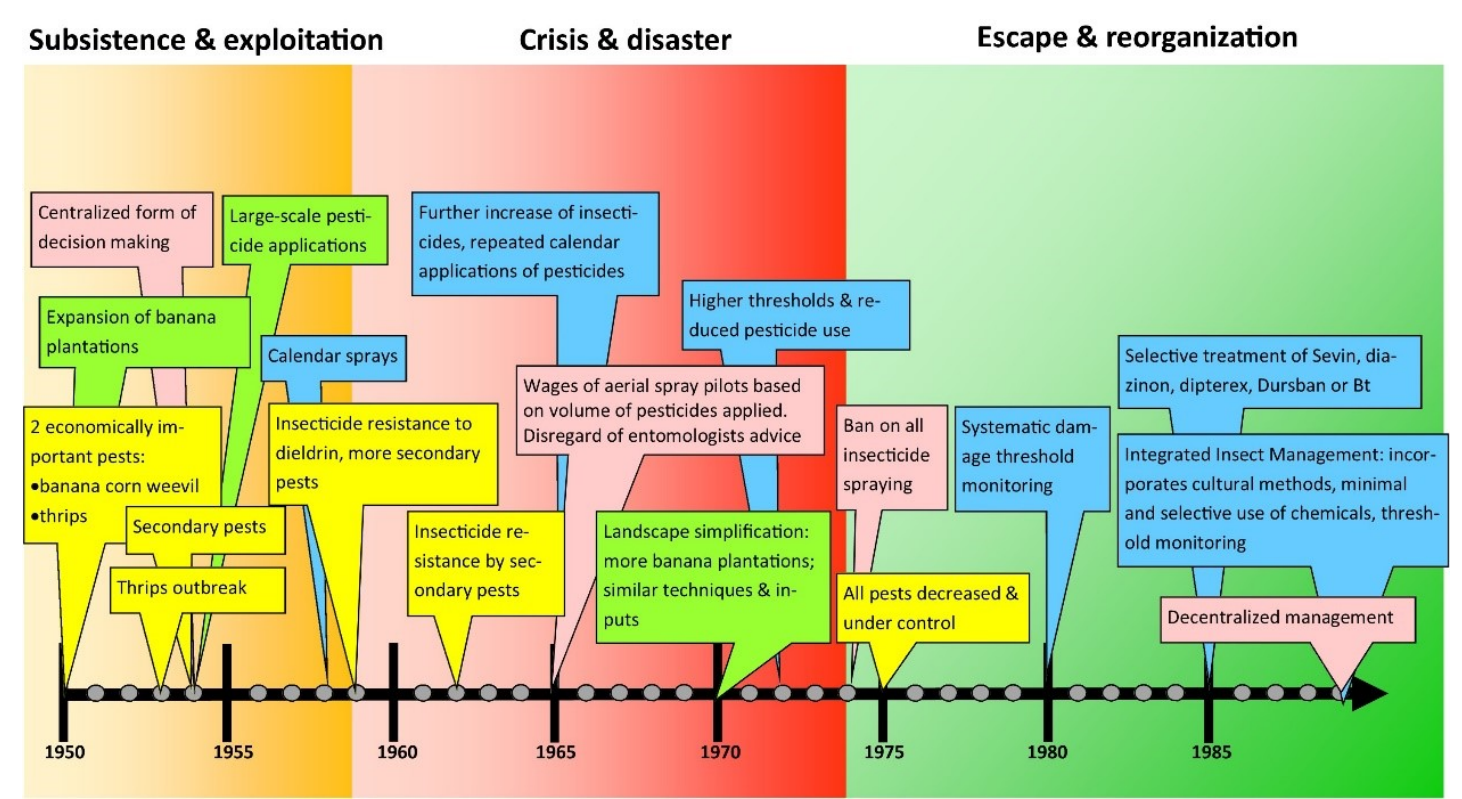

Figure A1.2: Timeline representing enabling and disabling drivers (text balloons) of pesticide use in banana production in the Golfito zone, Costa Rica from 1950-1990. Colours referring to domains in the framework: farming (yellow), agro-landscapes (green), science \& technology (blue), and society (pink). The colours in the background (orange-red-green) indicate the transition to a new phase of the treadmill.

\section{Case study Indonesia}

Subsistence \& exploitation

A fifth case is on rice production in Indonesia (Fig. A1.3). Rice production in Indonesia intensified in the 1960s as a result of rice intensification programs. Farmers were provided with a technology package consisting of short-duration, high-yielding rice varieties, nitrogen and phosphate fertilizers, insecticides and fungicides by the government. Farmers were obliged to use the whole package and applied pesticides on calendar-based regime, while problems due to yellow stem borers (Scirpophaga incertulas) maintained (Oka 1991, Settle et al. 1996, Thorburn 2015).

\section{Crisis \& disaster}

Government undertook contracts with insecticide firms for pest management activities, which included aerial applications of phosphamidon and diazinon to control stemborers. When a secondary pest, the brown planthopper (Nilaparvata lugens), emerged, the government provided loans and subsidies for agrochemicals to farmers. Another method to manage the brown planthopper was the development of resistant rice varieties (IR36) in the early 1980s, and the brown planthopper stopped being a problem until 1986. In 1984 Indonesia became self-sufficient in rice production. However, rice farmers were still dependent on chemicalbased pest management to control pest outbreaks from green leaf hoppers (Nephotettix malayanus and Nephotettix virescens) and white stemborer (Scirpophaga innotata) (Oka 1991, Settle et al. 1996, Thorburn 2015).

\section{Escape \& reorganization}

A large outbreak of the brown plant hopper in 1986 urged the president to ban 57 pesticides, along with the elimination of subsidies for insecticides. At the same time, IPM was introduced 
as the official state-endorsed approach to pest management and a large-scale program for farmer training in IPM was initiated. The program emphasized on-farm training that increased farmers' independence to implement IPM with as little external assistance as needed. Specific training was on pest surveillance, host-plant resistance, natural enemies of pests, judicious use of pesticides and field demonstrations that gave farmers first-hand experience with IPM practices and ecological concepts (Oka 2003, Bottrell and Schoenly 2012). Around 1.5 million farmers in Indonesia received training, and together with national IPM policies, insecticide use was reduced by as much as $75 \%$ (Oka 1991, 2003, Settle et al. 1996, Bottrell and Schoenly 2012).

\section{Crisis \& disaster}

The Asian Financial crisis in 1997-1998 hit Indonesia hard, and in combination with the political and economic turmoil in Indonesia during that period, many political and institutional changes have caused the National IPM Program to be degraded. In 2009, new outbreaks of the brown planthopper were reported with significant crop losses (Bottrell and Schoenly 2012). Concurrently, farmers started spraying again. This relapse to pesticide use is, amongst others, caused by insecticide resistance, deregulation and liberalization of trade and investment, decentralization of decision-making, and loss of communication pathways between agricultural research and extension services (Thorburn 2015).

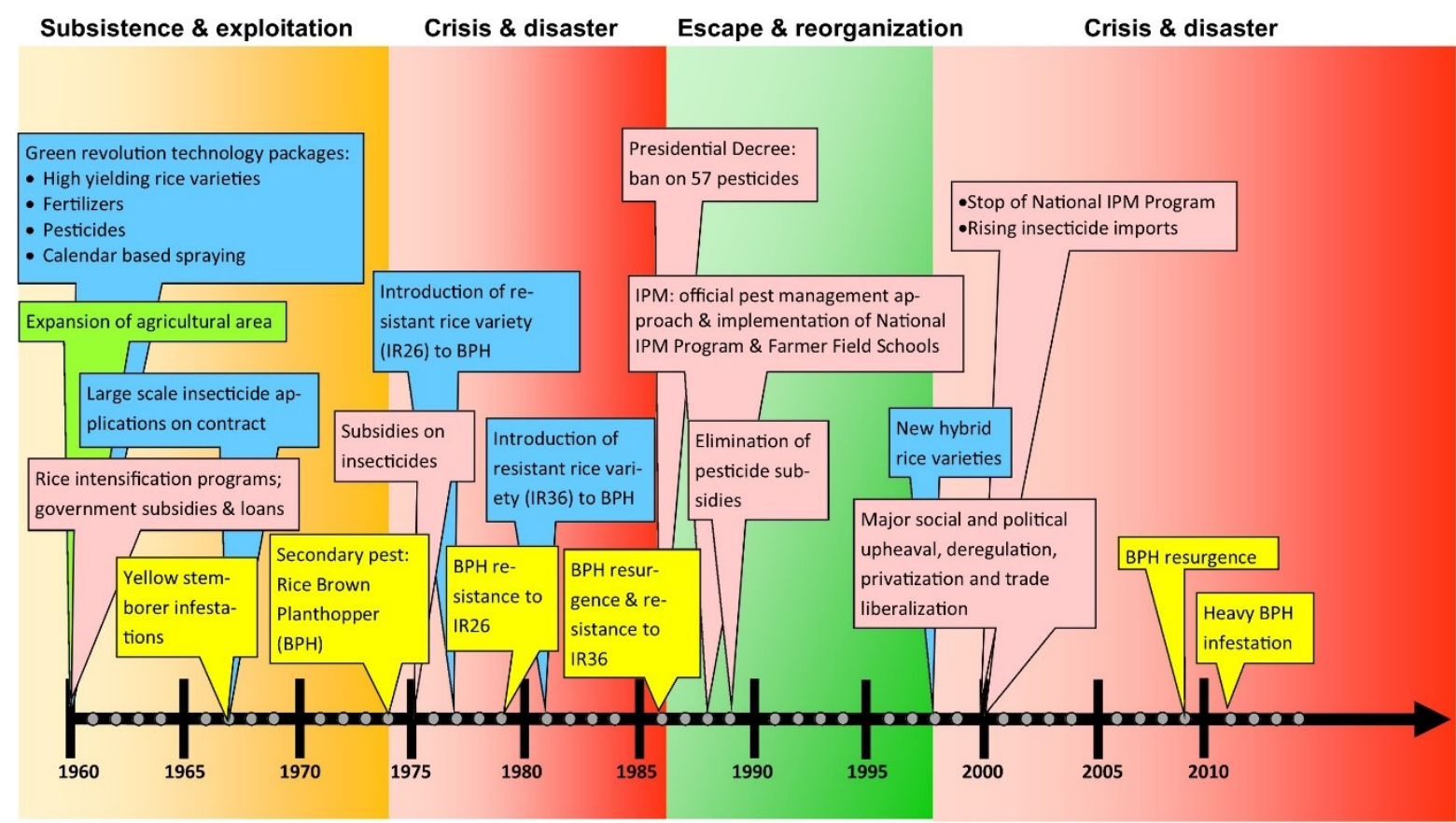

Figure A1.3: Timeline representing enabling and disabling drivers (text balloons) of pesticide use in rice production in Indonesia from 1960-2015. Colours referring to domains in the framework: farming (yellow), agro-landscapes (green), science \& technology (blue), and society (pink). The colours in the background (orange-red-green) indicate the transition to a new phase of the treadmill. 


\section{Literature cited}

Adkisson, P. L., G. A. Niles, J. K. Walker, L. S. Bird, and H. B. Scott. 1982. Controlling cotton's insect pests: a new system. Science 216:19-22.

Bottrell, D. G., and K. G. Schoenly. 2012. Resurrecting the ghost of green revolutions past: The brown planthopper as a recurring threat to high-yielding rice production in tropical Asia. Journal of Asia-Pacific Entomology 15(1):122-140.

Cowan, R., and P. Gunby. 1996. Sprayed to death: path dependence lock-in and pest control strategies. The Economic Journal 106(May):521-542.

Oka, I. N. 1991. Success and challenges of the Indonesia national Integrated Pest Management Program in the rice-based cropping system. Crop Protection 10:163-165.

Oka, I. N. 2003. Integrated Pest Management in Indonesia: IPM by Farmers. Pages 223-237 in K. M. Maredia, D. Dakouo, and D. Mota-Sanchez, editors. Integrated pest management in the global arena. CAB International.

Settle, W. H., H. Ariawan, E. T. Astuti, W. Cahyana, A. L. Hakim, D. Hindayana, and A. S. Lestari. 1996. Managing tropical rice pests through conservation of generalist natural enemies and alternative prey. Ecology 77:1975-1988.

Stephens, C. S. 1984. Ecological upset and recuperation of natural control of insect pests in some Costa Rican banana plantations. Turrialba 34:101-105.

Thorburn, C. 2015. The rise and demise of integrated pest management in rice in Indonesia. Insects 6:381-408.

Thrupp, L. A. 1990. Entrapment and escape from fruitless insecticide use. International Journal of Environmental Studies 36:173-189. 